\title{
Relationships between latitude and environmental conditions and the species richness, abundance and composition of tropical fish assemblages over soft substrata
}

\author{
Michael J. Travers ${ }^{1,2,3, *}$, Ian C. Potter ${ }^{1}$, K. Robert Clarke ${ }^{1,4}$, Stephen J. Newman ${ }^{3}$ \\ ${ }^{1}$ Centre for Fish and Fisheries Research, School of Biological Sciences and Biotechnology, Murdoch University, \\ Western Australia 6150, Australia \\ ${ }^{2}$ Australian Institute of Marine Science, University of Western Australia Oceans Institute, Crawley, Western Australia 6009, \\ Australia \\ ${ }^{3}$ Western Australian Fisheries and Marine Research Laboratories, Department of Fisheries, Government of Western Australia, \\ North Beach, Western Australia 6920, Australia \\ ${ }^{4}$ Plymouth Marine Laboratory, Prospect Place, West Hoe, Plymouth PL1 3DH, UK
}

\begin{abstract}
Large-scale studies are required to elucidate the environmental factors that structure faunal communities. The relationships between the characteristics of the coastal ichthyofaunas over the soft substrata of tropical north-western Australia and both latitude and environmental factors were thus explored by analysing trawl data obtained for deep and shallow inshore waters at 7 regularly spaced locations along this $1500 \mathrm{~km}$ coast during both the dry and wet seasons. In the dry season, species richness and density were greater in the Kimberley and Pilbara bioregions than in the intervening Canning bioregion, where, in contrast to particularly the Kimberley, rivers and mangroves are largely absent. Species richness and density were greatest in the most northern bioregion (Kimberley) during the wet season, when nutrient input from rivers and water temperatures were highest. The high species richness and density at 1 Canning location during the wet season was presumably related to increased productivity brought about by local cyclonic events. Ichthyofaunal compositions in the Kimberley differed markedly from those in the Canning and Pilbara, where tidal range was less and water clarity greater due, in particular, to far greater densities of leiognathids and terapontids. Compositions at all locations in the dry season differed from those in the wet, when chlorophyll a concentrations and/or water temperatures were greatest and large numbers of certain species were recruited. Ichthyofaunal composition at each location almost invariably differed markedly between water depths, reflecting, inter alia, the tendency for some species to use nearshore waters as nursery areas and for others to occupy particular habitats.
\end{abstract}

KEY WORDS: Tropical north-western Australia - Ichthyofaunal characteristics - Bioregions · Season (wet vs. dry) $\cdot$ Water depth $\cdot$ Productivity $\cdot$ Mangroves $\cdot$ Cyclonic effects

Resale or republication not permitted without written consent of the publisher

\section{INTRODUCTION}

The species richness, density and composition of faunal communities, including those of marine fishes, typically change with latitude, partly reflecting pro- gressive changes in water temperature (Bellwood \& Hughes 2001, Connolly et al. 2003, Hawkins \& Diniz 2004, Travers et al. 2010) and productivity (Robertson \& Blaber 1992, Manson et al. 2005a,b). These biotic variables also vary with distance from shore, due to 
certain species tending to occupy either shallow or deeper waters and/or moving into and out of areas at different stages in their life cycle (e.g. Bianchi 1992, Blaber et al. 1994b, 1995, Connell \& Lincoln-Smith 1999, Gaertner et al. 1999, Hyndes et al. 1999). Although the species compositions of fish communities often change cyclically during the year (e.g. Hyndes et al. 1999, Kuo et al. 2001, Travers \& Potter 2002), they can also alter abruptly, e.g. when waters become turbid during cyclones (Jones \& Syms 1998, Cheal et al. 2002). Species composition, species richness and density also differ among habitats, e.g. between reefs and soft substrata, and between unvegetated substrata and seagrass meadows (e.g. Heck et al. 1989, Guidetti 2000, Travers \& Potter 2002), even when differences are more subtle, such as those resulting from variations in the characteristics of soft substrata (Harris \& Poiner 1991, Blaber et al. 1994b, 1995).

The climate along the remote and extensive coastline of tropical north-western Australia (NWA) undergoes extreme changes during the year, with the dry season, which extends from May to October, leading into a very wet cyclonic season between November and April (Gentilli 1972). During the warm wet season, the large volume of freshwater discharged from the large rivers along the Kimberley coast results in substantial amounts of nutrients entering inshore waters (Holloway et al. 1985, Condie \& Dunn 2006) and thus presumably to an increase in plankton density and ultimately the amount of food for fishes.

The NWA coast comprises 3 bioregions, i.e. the Kimberley, Canning and Pilbara, which differ markedly in such features as tidal range, turbidity, rainfall and the prevalence of rivers (Semeniuk 1993, Thackway \& Cresswell 1998). Furthermore, in comparison with the Kimberley and Pilbara coasts, the Canning coast is less productive (Condie \& Dunn 2006, P. Thompson pers. comm.) and does not contain extensive mangrove forests, which typically provide protection for fishes (Blaber \& Blaber 1980, Robertson \& Duke 1990, Blaber et al. 1995). The most northern of these regions lies immediately to the south of the Indo-Australian Archipelago (IAA), in which the species richness of its ichthyofaunas is the greatest of any marine waters (Hughes et al. 2002, Connolly et al. 2003). The NWA coast also contains a diverse and abundant fish fauna (Blaber et al. 1985, Hutchins 2001, Travers et al. 2006, 2010).

A recent study, using data derived from sampling fishes by trapping over reefs and by trawling over soft substrata in deep and shallow inshore waters along the $1,500 \mathrm{~km}$ coastline of tropical NWA, demonstrated that the characteristics of the fish com- munities on this coast differ markedly between the above 2 habitat types and among bioregions, and changed progressively with latitude, presumably reflecting, in part, the influence of water temperature (Travers et al. 2010). The data for dry and wet seasons and both water depths at each location were pooled for that broad overarching study. More detailed analyses of the trapping data showed that the compositions of the fish communities over reefs were related to season and especially water depth (Travers et al. 2006). The trawl data for soft substrata have not been subjected to detailed analyses and no attempt has been made to elucidate how the species richness, density and species composition of fishes over such substrata along the NWA coast are related to season and water depth and how changes in species composition are related to a range of other environmental variables.

Large-scale studies are crucial for elucidating the factors that are most important in structuring faunal communities (Mahon et al. 1998, Gaertner et al. 2005) and for providing the data required to develop strategies for protecting tropical coastal ecosystems. Thus, in the present study, data derived from trawling at regular intervals along the NWA coastline were collated to quantify the densities of each fish species over soft substrata in deep and shallow inshore waters in dry and wet seasons at 7 locations distributed among the 3 coastal bioregions of tropical NWA. The data for the Kimberley, Canning and Pilbara bioregions were then subjected to univariate and multivariate analyses to address the following hypotheses: (1) The species richness and densities of fishes are greatest in the Kimberley and Pilbara bioregions, where the productivity of inshore waters is greatest, and the nearshore waters of particularly the Kimberley contain extensive mangrove forests. (2) The species richness and density of fishes in the Kimberley are far greater in the wet season than in the less productive dry season. (3) Ichthyofaunal composition differs between seasons and water depths at each location. The species that contribute most to any differences between the ichthyofaunal compositions of the 3 bioregions and between those in the 2 seasons and depths at each location will be determined. Finally, a matrix derived from the densities of the fish species caught over soft substrata in both water depths in the wet and dry seasons will be subjected to a multivariate regression tree procedure to elucidate which of a suite of environmental variables are most important in helping to explain any divisive clustering of ichthyofaunal compositions among locations and bioregions along the length of the tropical NWA coast. 


\section{MATERIALS AND METHODS}

\section{Study area}

The inner shelf $(<30 \mathrm{~m}$ depth) of tropical NWA, comprising the Kimberley bioregion in the north, the Canning in the centre and the Pilbara in the south (Semeniuk 1993, Thackway \& Cresswell 1998), is characterized by large tidal ranges that decline in amplitude from north to south. The tidal ranges in the Kimberley exceed $10 \mathrm{~m}$ during spring tides and are thus among the highest of any open coastline in the world (Holloway 1983). The combination of strong tidal currents ( 8 to $22 \mathrm{~km} \mathrm{~h}^{-1}$ ) and large seasonal discharge from rivers along the Kimberley coast result in the turbidity of its inshore waters, in especially the wet season, being far greater than in those of the Canning coast, where tidal influence is not as strong and large rivers are not present; and, even more particularly than those of the Pilbara coast, where tidal range is least and its few large rivers flow only occasionally (Semeniuk 1993). Rainfall along most of the
NWA coastline is high and occurs mainly during the Austral summer (November to April), when it is subjected to the highest frequency of cyclones of any coast in Australia (Porter-Smith et al. 2004), thus producing very distinct and alternating wet and dry seasons (Lough 1998). Mangrove forests are abundant and dense in the river and creek mouths and nearshore coastal waters of the Kimberley and, to a lesser extent, of certain parts of the Pilbara (Semeniuk 1993).

\section{Sampling regime and environmental data}

Fishes were sampled by otter trawling over soft substrata in deep $(\bar{x}=22 \mathrm{~m})$ and shallow $(\bar{x}=12 \mathrm{~m})$ inshore waters at 7 regularly-spaced locations along the Kimberley (Cape Voltaire and Hall Point), Canning (Emeriau Point, Cape Bossut and Cape Keraudren) and Pilbara (Cape Preston and Locker Point) coasts (Fig. 1). Trawling was undertaken during the day in the dry season of 2001 (June to August) and

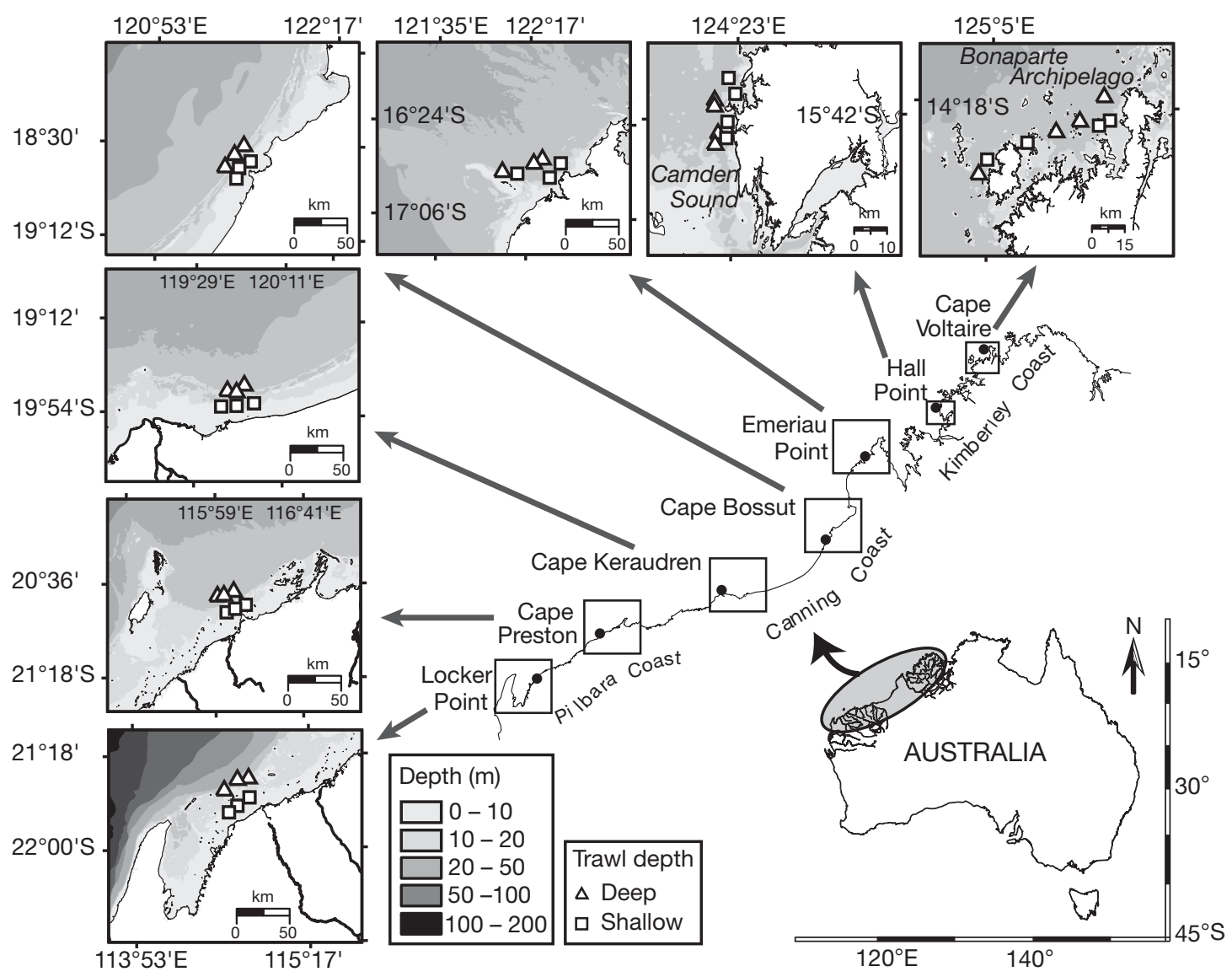

Fig. 1. The 7 trawling locations at 3 bioregions in tropical north-western Australia were sampled in deep ( $\bar{x}=22 \mathrm{~m})$ and shallow $(\bar{x}=12 \mathrm{~m})$ inshore waters 
wet season of 2002 (February to April). The trawl comprised port and starboard nets, each having a foot-rope length of $30.5 \mathrm{~m}$, with 50 and $45 \mathrm{~mm}$ stretched mesh in the wings and cod-end, respectively. When in operation, the mouth of the net was $8 \mathrm{~m}$ wide and $1 \mathrm{~m}$ high. In both sampling seasons, 4 replicate trawls of $15 \mathrm{~min}$ duration were carried out at a boat speed of $\sim 5$ to $7 \mathrm{~km} \mathrm{~h}^{-1}$ in each water depth at each location during the slack-water phase of the tidal cycle, with each replicate trawl covering a distance of 1.1 to $1.7 \mathrm{~km}$ and being separated by a distance of at least $500 \mathrm{~m}$ from that of all other replicate trawls. Sampling did not commence until at least $1 \mathrm{~h}$ after sunrise and was completed at least $1 \mathrm{~h}$ before sunset (Koslow et al. 1997). The area swept during each trawl was calculated from the width of the net's mouth and the distance trawled, the latter being determined from the latitudes and longitudes at the start and finish of each trawl. The catches of the port and starboard nets in each trawl were pooled prior to processing. Note that, as our study sites were in locations either outside the range of commercial fishing or in those where such fishing was infrequent, the influence of commercial fishing on the ichthyofaunal characteristics at our sites would have been minimal at best.

Water temperature and depth, secchi disc depth (depth of water clarity) and distance from mainland shore, were recorded immediately prior to undertaking each replicate trawl. The extent of substratum hardness and complexity were estimated by a combination of visual assessment of the ship's sonar signal, video footage from a drop camera as the ship passed along the trawl track and inspection of the biota retained in the trawl cod-end. The substratum covered during each trawl was categorised as either soft mud, soft sand, soft sand with sparse sponges, hard sand, hard sand with sparse sponges or hard sand with sponge and live gorgonian fragments. The tidal range at a site on the day of sampling was recorded as the difference between the maximum and minimum water heights at that site on that day, while precipitation was recorded as the total rainfall during sampling and in the preceding $2 \mathrm{wk}$. Tidal range and precipitation data were obtained from the Australian Government Bureau of Meteorology. Average estimates of remotely-sensed chlorophyll (chl) a concentrations during 5 mo in the dry (May to September 2001) and wet (December 2001 to April 2002) seasons were calculated with the Giovanni online data system, developed and maintained by the NASA GES DISC (Acker \& Leptoukh 2007). Note that chl a concentration at the ocean's surface in an area can be used to estimate phytoplankton standing stocks and thus the productivity in those waters (Morel \& Berthon 1989, Behrenfeld et al. 2006).

Each fish caught was identified to species using the descriptions in Gloerfelt-Tarp \& Kailola (1984), Sainsbury et al. (1985), Last \& Stephens (1994), Allen (1997) and Carpenter \& Niem (1998-2001). The number and wet weight of each species in each sample were recorded and expressed as the number and biomass of fishes $0.01 \mathrm{~km}^{-2}$, respectively. As in the trawl study of Williams et al. (2001), catchability (q) was regarded as 1 because there was no information on the selectivity of our gear. Note, however, that the vast majority of our species belong to the small and medium-sized categories, which, in the study of Blaber et al. (1990) using a fish trawl, did not differ markedly in their values for q. Since Saurida undosquamis and Saurida sp. 2 are morphologically indistinguishable and thus require genetic techniques for their specific identification (Thresher et al. 1986), they were collectively recorded as Saurida spp.

\section{Statistical analyses}

Three-way ANOVAs were used to determine whether water temperature and depth of water clarity and species richness and total density of fishes differed among locations and between dry and wet seasons and water depths. Note that ANOVAs were not carried out on other environmental variables because, unlike temperature and water depth, only single values were computed for those variables for each combination of site, season and depth. Prior to ANOVA, and separately for each of the 4 variables, the relationship between the mean and standard deviation for each location, depth and season combination determined the choice of transformation to satisfy homoscedasticity (Clarke \& Warwick 2001). Water temperature and clarity required square-root transformations, species richness a 4th-root and density a $\log _{\mathrm{e}}$ transformation, the transformed variables then also satisfying the weak requirements for normality in ANOVA.

The $\log _{\mathrm{e}}$ densities of each fish species were used to construct a Bray-Curtis similarity matrix. The data were considered to represent a 3-way fully crossed design that comprised location ( 7 levels $) \times$ season $(2$ levels, i.e. wet and dry) $\times$ water depth $(2$ levels, i.e. deep and shallow), with each factor being fixed. This matrix was subjected to a Permutational Multivariate Analysis of Variance (PERMANOVA; Anderson 
2001, Anderson et al. 2008) to test whether there were significant interactions between the above 3 factors. These formal test results were then interpreted in the following 2 ways: (1) by examining plots of non-metric multi-dimensional scaling (nMDS) ordinations based on Bray-Curtis similarities, which were carried out using either the original replicate data, sub-divided by location in this case, or the averaged data matrix over replicates of the log-transformed densities (Clarke \& Gorley 2006), plotted for all locations; (2) by determining the average influence of the location, season and depth effects, using 3 two-way crossed ANOSIM analyses (Clarke 1993) for (i) location (latitude) versus the combined effects of season and depth (i.e. including their interaction), (ii) season versus the combined effects of location and depth, and (iii) depth versus the combined effects of location and season. This was achieved by combining the values for the 2 removed factors in each case to a single factor representing all combinations of their levels. The resulting 2-way ANOSIM statistic $\bar{R}$ for example in case (i), is the average of the seven 1-way ANOSIM $R$ statistics for testing among locations separately for each of the 4 combinations of depth and season ( $R$ captures the difference between 'among location' and 'within location' rank dissimilarities). The $\bar{R}$ value is therefore instructive as a measure of the overall magnitude of the location effect (whether this comes from main effects, interaction terms or both), which can then be compared with the similar 2-way $\bar{R}$ statistics for season and depth from cases (ii) and (iii). However, $\bar{R}$ of itself does not differentiate between situations where its constituent $R$ values are consistent (main effect) or inconsistent (interactions), so it is useful, where PERMANOVA indicates the likely presence of interactions, to subdivide the ANOSIM analyses accordingly.

ANOSIM analyses are the preferred approach at this interpretational stage for 3 main reasons: (1) the robustness of a fully non-parametric procedure (note that PERMANOVA is not fully non-parametric, since it depends on the measurement scale of the similarities rather than their ranks); (2) the exact match between rank-based ANOSIM tests and the most effective of the ordination techniques for displaying complex high-dimensional data in low-dimensional space, namely nMDS; (3) the direct interpretability of the ANOSIM $R$ and $\bar{R}$ statistics as universally scaled measures of group separation. Whatever the chosen similarity measure, or its scaling, the value of $R$ ranges from near 0 , for little or no separation of the groups being compared, up to $R$ near 1, for 'complete' separation, meaning that no 2 replicates from different groups are closer in community structure than any pair of replicates taken from the same group.

Where testing showed the presence of non-negligible differences, 2-way crossed similarity percentage analyses (SIMPER; Clarke \& Gorley 2006) were used to identify the fish species that typified the species composition of each a priori group and those which were responsible for distinguishing between the compositions in each pair of groups. Using the full replicate data, the RELATE procedure (Clarke \& Gorley 2006) was used to quantify the extent to which the pattern of rank orders between the ichthyofaunal compositions of the various samples in the biotic similarity matrix, derived from the density data used in the nMDS ordination analyses, paralleled those in distance matrices constructed at higher taxonomic levels, i.e. genus, family, sub-order, order and super-order (Somerfield \& Clarke 1995). The Spearman rank correlation ( $\rho$ ) was used to assess the extent to which the multivariate structure of the 2 matrices agreed.

The following application of the Linkage Tree (LINKTREE; Clarke et al. 2008) routine was used to examine which thresholds of the 8 environmental variables (water temperature and depth, mean spring tidal range, depth of water clarity, chl $a$, rainfall, distance to shore and substratum type) were indicative of the successive separation of sites into subgroups from a constrained divisive cluster analysis. LINKTREE is a non-metric modification of the multivariate regression tree approach of De'Ath (2002). Thus, a binary 'linkage tree' is constructed that reflects how samples from an underlying (biotic) resemblance matrix are most naturally split into successively smaller groups, based on maximising the ANOSIM $R$-statistic (Clarke 1993) for a binary split of each group, allowable divisions being constrained to those for which at least 1 of the environmental variables takes larger values for all samples in one of the subgroups than those in the other subgroup. At each branching node of the tree, quantitative thresholds are therefore provided of the variables from explanatory data, e.g. environmental values that mirror the division in the biological samples. In theory, the terminal group to which any new multivariate sample could be assigned is thus determined by ascertaining whether its values for the variables specified at each successive node of the tree are less than or greater than the given thresholds.

The LINKTREE procedure was applied to the BrayCurtis similarity matrix calculated from the data 
averaged over replicates, the explanatory variables being the untransformed measurements for the 8 environmental variables, also averaged for each combination of location, season and depth. A similarity profile permutation test (SIMPROF; Clarke et al. 2008) was used in conjunction with LINKTREE to provide stopping rules for the successive subdivisions at those nodes at which no significant multivariate structure was deemed to be present among the remaining biological samples, using $p>0.05$ as the significance criterion. The LINKTREE and SIMPROF routines thus produce a constrained divisive clustering in which terminal nodes comprise groups of sites with high internal similarity, together with a sequence of inequalities on the environmental variables that 'explain' each biotic group. It is recognised that no inference of causality is possible with such an observational study.

All of the preceding multivariate analyses were carried out using the PRIMER v6 multivariate statistics package (Clarke \& Gorley 2006), together with the PERMANOVA+ add-on module where appropriate (Anderson et al. 2008).
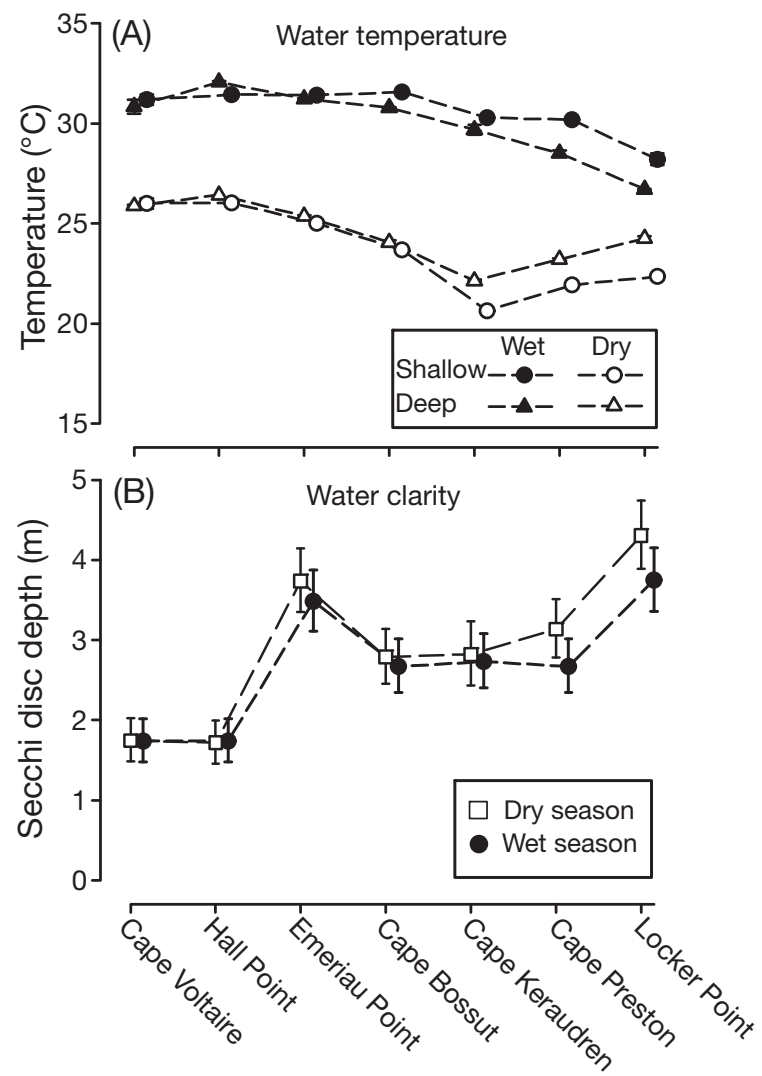

Fig. 2. Mean values $( \pm 95 \% \mathrm{CI})$ for $(\mathrm{A})$ water temperatures and (B) water clarity depths at each of the 7 sampling locations in tropical north-western Australia. Note error bars are too small in the first plot to be effectively illustrated

\section{RESULTS}

\section{Environmental variables}

While, as demonstrated by ANOVA, water temperature differed significantly between dry and wet seasons and among locations (both $p<0.001$ ) and between water depths $(p<0.05)$, there were significant interactions for location $\times$ depth, location $\times$ season and depth $\times$ season for this variable. The mean square values emphasized, however, that temperature was more strongly related to season (9.8) than either location (0.32) or water depth (0.005), and that season and location had a far greater influence on temperature than the interactions. At each location, water temperatures in both depths were far greater during the wet than dry seasons (Fig. 2A). Although water temperatures at the more northern locations were similar in deep and shallow waters in the wet and dry seasons, they increasingly diverged with depth in a southwards direction during both seasons, but with those for shallow water becoming greatest in the wet and those for deep water becoming greatest in the dry. These differences account for the interactions between location, depth and season.

The mean depth of water clarity differed significantly among locations $(\mathrm{p}<0.001)$ and between seasons $(\mathrm{p}<0.05)$, but not between water depths $(\mathrm{p}>$ $0.05)$, and there were no significant interactions between these variables $(p>0.05)$. Water clarity was related more to location (mean square $=1.10$ ) than season (mean square $=0.09$ ). Water clarity was least at Cape Voltaire and Hall Point in the north $(\sim 1.7 \mathrm{~m})$ and greatest at Locker Point in the south (Fig. 2B). Although water clarity was very similar in the wet and dry seasons at the 2 most northern locations (Cape Voltaire and Hall Point), it was greater during the dry season at the other 5 locations and particularly at the 2 most southern locations (Cape Preston and Locker Point).

\section{Dominant species and families}

Trawling in deep and shallow inshore waters at the 7 locations along the NWA coast in 2001 and 2002 yielded 84781 fishes, which represented 272 species of teleost belonging to 167 genera and 74 families (Table 1). None of the 13 elasmobranch species, representing 9 genera and 6 families, was abundant or regularly caught.

Certain species showed a pronounced tendency to occur either exclusively or predominantly in certain 


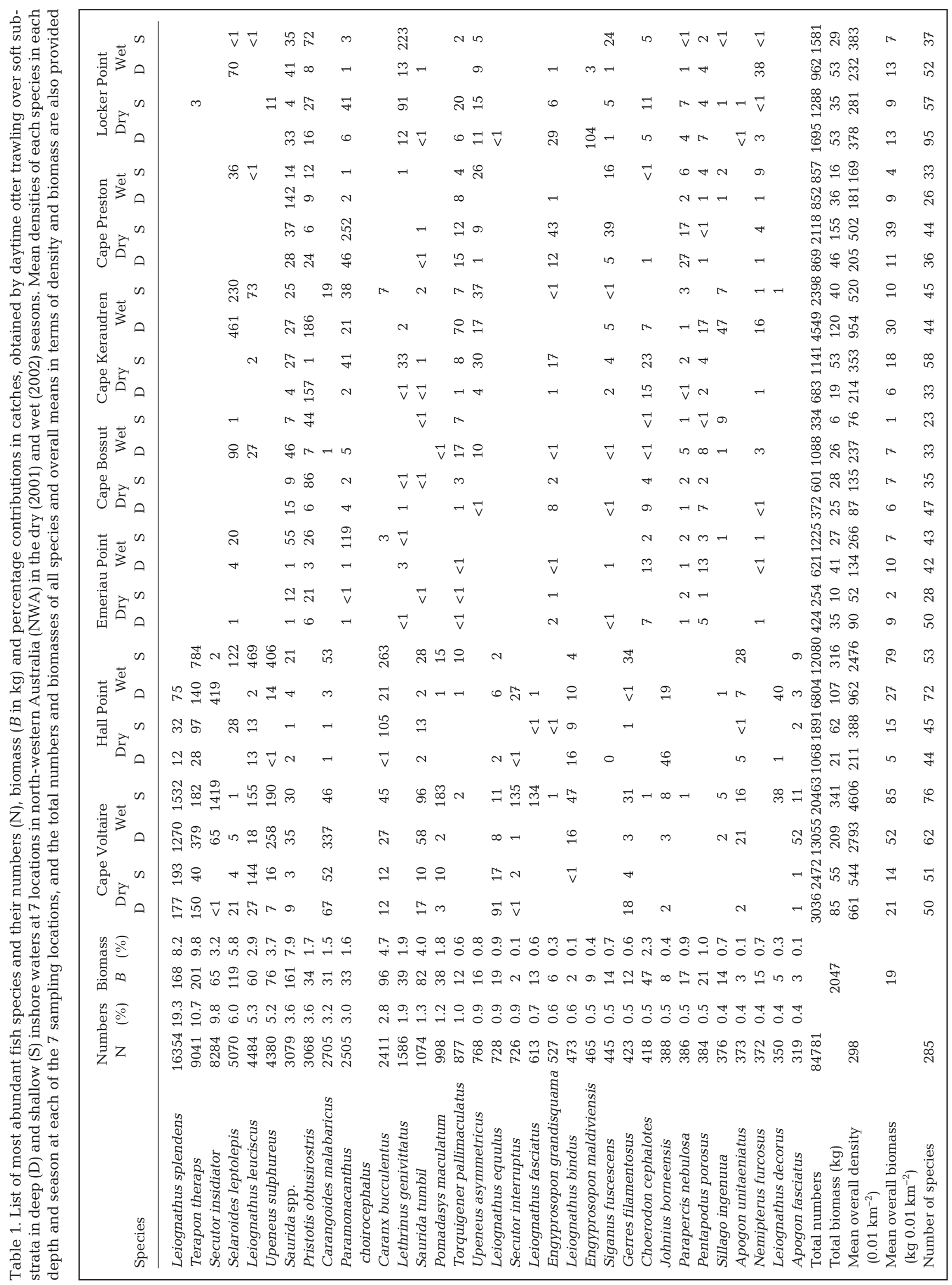


locations, seasons and/or water depths. For example, Leiognathus splendens, Secutor insidiator and Terapon theraps were all very abundant in samples from Cape Voltaire and Hall Point in the Kimberley, whereas they were caught at only 1 of the 5 locations in the Canning and Pilbara regions further south, and even then were represented by only 3 individuals of a single species (Table 1). In contrast, the reverse trend was exhibited by Pristotis obtusirostris and Paramonacanthus choirocephalus, while species such as Selaroides leptolepis and Saurida spp. were regularly present in samples taken along the NWA coast.

For Leiognathus splendens, Secutor insidiator, Selaroides leptolepis, and L. leuciscus which ranked $1 \mathrm{st}, 3 \mathrm{rd}, 4 \mathrm{th}$ and 5 th, respectively, in terms of overall abundance, the numbers of each of these species were greater during the wet season, whereas the reverse was true for Engyprosopon grandisquama (Table 1). At locations where they were recorded, $L$. leuciscus, Paramonacanthus choirocephalus, Caranx bucculentus and Saurida tumbil tended largely to be more abundant in shallow than deeper waters, while the opposite was true for Leiognathus equulus and Pentapodus porosus.

The Leiognathidae contributed $\sim 40 \%$ to the total catch of fishes, with only the Carangidae and Terapontidae otherwise contributing $>10 \%$ (Table 2). The Leiognathidae at Cape Voltaire and Hall Point, the locations to which this family was largely confined, contributed more to the wet than dry seasons (Table 2). When the Monacanthidae was abundant at a location, it tended to contribute more to the numbers in shallow than deeper waters, whereas the reverse was almost invariably the case with the Labridae (Table 2). In terms of their percentage contributions to the catches, the Leiognathidae, Carangidae and Terapontidae ranked 1st, 2nd and 3rd, respectively, in both deep and shallow waters; the Leiognathidae likewise ranked 1st in the dry and wet seasons, and the Carangidae also ranked 2nd in the wet season and was 3rd in the dry season (Table A1 in the Appendix). While the Monacanthidae ranked 2nd in the dry season, it ranked only 7 th in the wet season and 5th in shallow water and did not rank amongst the top 10 in deep water. Although the Leiognathidae ranked 1st in both water depths and both seasons, their total numbers in shallow water exceeded those in deep water by 1.9 times and those in the wet season exceeded those in the dry season by as much as 8.0 times. In contrast, there were only small differences in the abundances of the Carangidae in deep and shallow water and between the
Pomacentridae in the dry and wet seasons. This emphasises the importance of taking into account both the percentage contributions and abundances when comparing species in different water depths and seasons.

\section{Species richness and density of fishes}

Although the species richness and density of fishes were both significantly related to location and also to season in the case of density, there were appreciable interactions for location $\times$ season for both of these biotic variables and for location $\times$ depth $\times$ season for density (Table 3 ). However, the mean squares for both location and season in the case of richness and for season with density were far greater than those for the respective interactions for those biotic variables. In the dry season, the mean species richness and density in deep water declined from high values at the 2 most northern locations to their minimum at geographically intermediate locations, and then rose at the most southern locations (Fig. 3A,C). While the species richness and density in shallow water during the dry season followed similar trends, they tended to decline in the most southern part of the Pilbara in that season (Fig. 3A,C). The mean species richness and density in deep and shallow waters in the wet season likewise initially declined in a southwards direction, but subsequently peaked sharply at Cape Keraudren and then declined to lower levels at the 2 locations in the Pilbara (Fig. 3B,D). The strong location $\times$ season interaction for species richness and density reflects the fact that, in contrast to the situation in the dry season, the values for both of these biotic variables in the wet season are far greater in the northern than southern locations (Fig. 3).

\section{Relationships between species composition and season and water depth}

While species composition was shown by PERMANOVA to be significantly related to location, season and depth, there were significant interactions between location and both season and depth, and between each of these 3 factors (Table 4). The 2-way crossed ANOSIM test, using location and a combined season-by-depth factor, thus removing any confounding influence of season and/or depth individually, gave an $\bar{R}$-statistic value of 0.85 for location, while the $\bar{R}$-statistic for season, removing the combined effects of location and depth, was 0.72 , and 


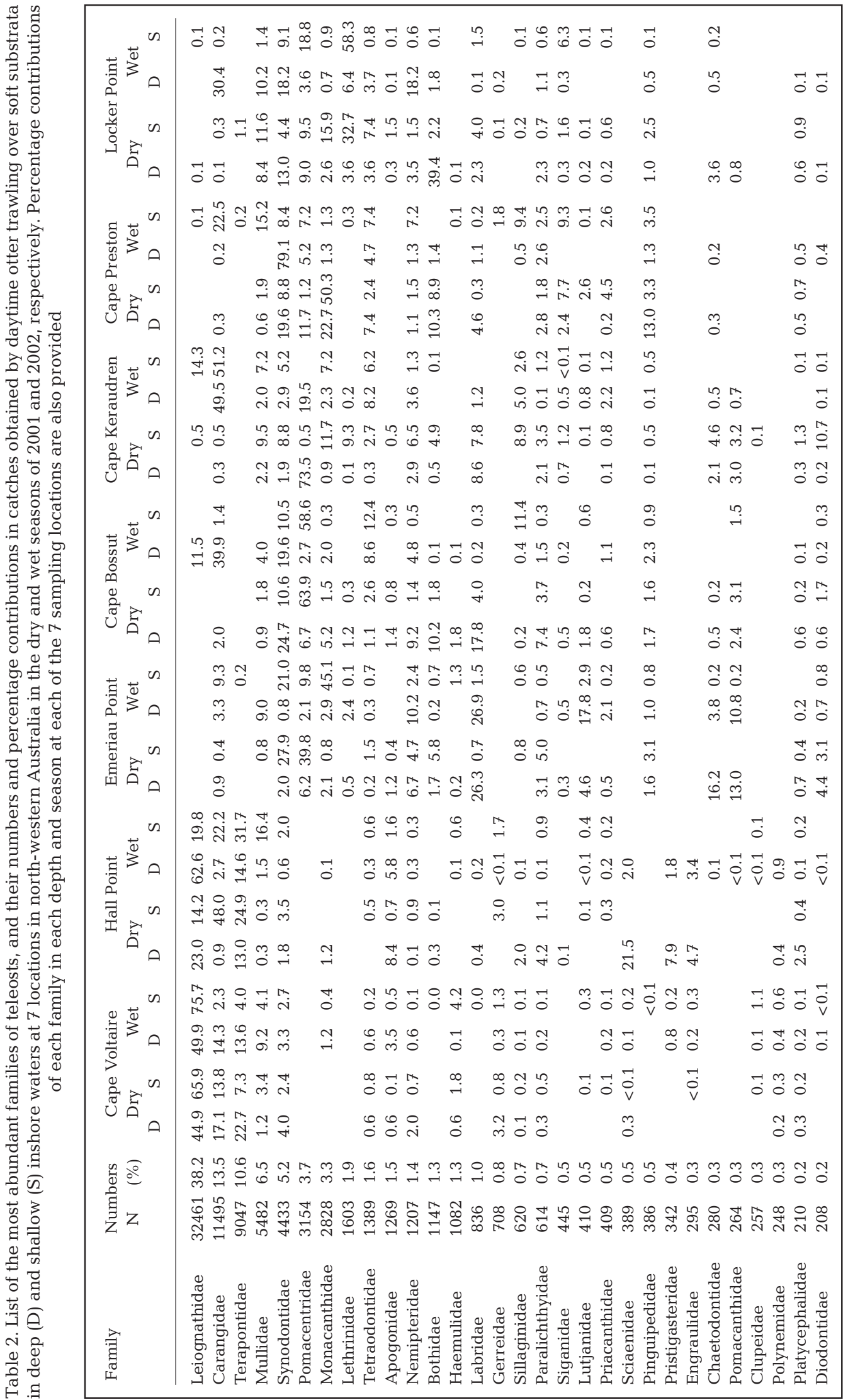


Table 3. Mean squares (MS), F-values and their significance levels (p) for ANOVAs of number of fish species and density of fishes in deep and shallow waters at 7 locations along the coast of north-western Australia in the dry (2001) and wet (2002) seasons

\begin{tabular}{|lcrrrrrrr|} 
& df & \multicolumn{3}{c}{ Number of species } & \multicolumn{4}{c|}{ Density } \\
& & MS & $F$ & $p$ & MS & $F$ & p \\
\hline Location & 6 & 5.528 & 12.3 & $<0.001$ & 2.507 & 37.7 & $<0.001$ \\
Season & 1 & 0.194 & 0.4 & 0.512 & 2.648 & 39.8 & $<0.001$ \\
Depth & 1 & 0.824 & 1.8 & 0.178 & 0.231 & 3.5 & 0.066 \\
Location $\times$ Season & 6 & 2.451 & 5.5 & $<0.001$ & 0.589 & 8.9 & $<0.001$ \\
Location $\times$ Depth & 6 & 1.288 & 2.9 & 0.013 & 0.092 & 1.4 & 0.230 \\
Season $\times$ Depth & 1 & 0.034 & 0.1 & 0.784 & 0.003 & 0.1 & 0.838 \\
Location $\times$ Season $\times$ Depth & 6 & 0.955 & 2.1 & 0.058 & 0.310 & 4.7 & $<0.001$ \\
Residual & 82 & 0.447 & & & 0.066 & & \\
& & & & & & & & \\
\end{tabular}
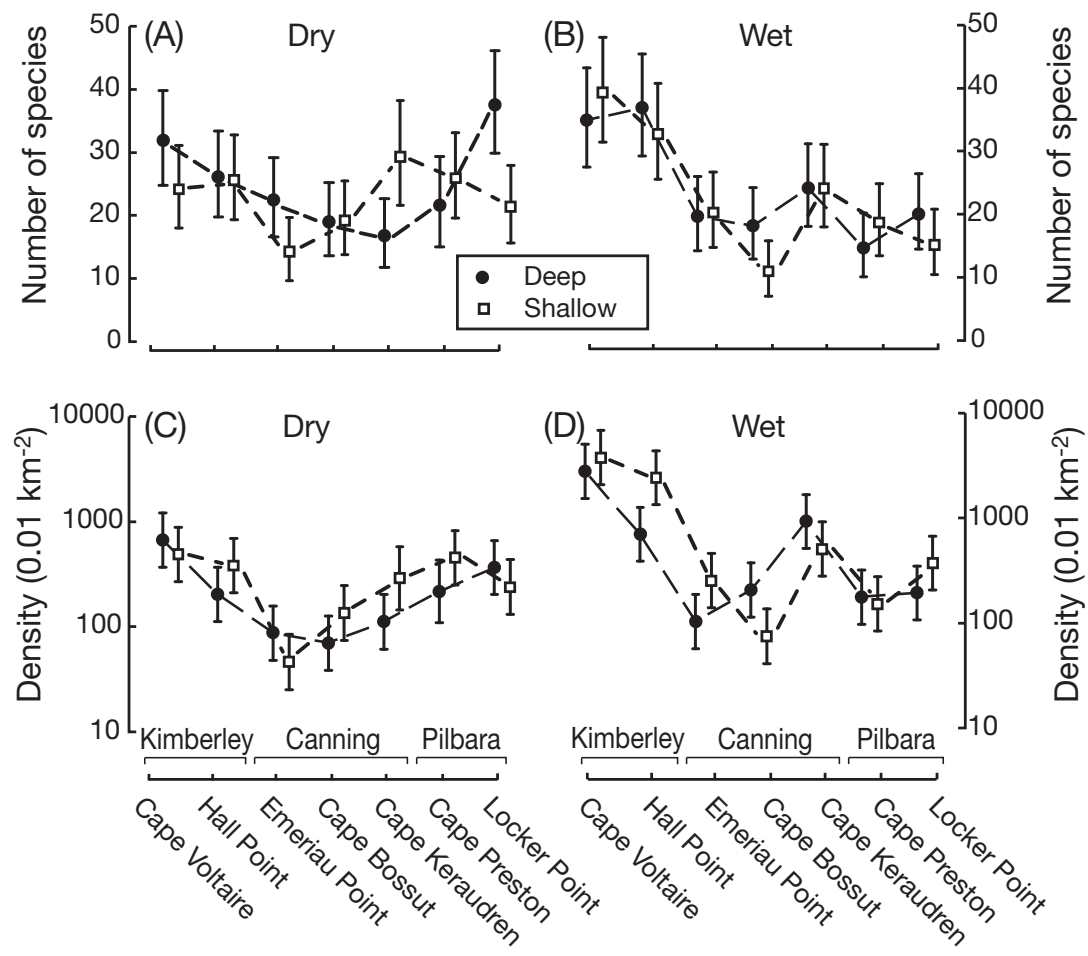

Fig. 3. Mean values $( \pm 95 \% \mathrm{CI})$ for $(\mathrm{A}, \mathrm{B})$ species richness and $(\mathrm{C}, \mathrm{D})$ densities of fish in the $(A, C)$ dry and $(B, D)$ wet seasons of 2001 and 2002, respectively, from deep and shallow waters at 7 trawling locations in north-western Australia

$0.6 \%$ ), with $\bar{R}$-statistic values ranging from 0.17 for Cape Preston versus Locker Point to 1.0 for Cape Voltaire versus Cape Preston. In general, the $\bar{R}$-statistic values for comparisons between the faunal compositions in adjacent locations were far less than those between widely-separated locations. Species that made major contributions to the differences in the ichthyofaunal compositions among locations included Terapon theraps, Leiognathus leuciscus and L. splendens, which were in far greater densities and more regularly caught at Cape Voltaire and/or Hall Point than at any of the southern locations (Table A2 in the Appendix). In contrast, greater contributions of Paramonacanthus choirocephalus distinguished the fauna at Cape Preston from all other locations.

The demonstration by PERMANOVA and ANOSIM tests that ichthyofaunal composition is influenced by location, season and water depth is borne out by the nMDS ordination plot shown in Fig. 4, in which the samples from Cape Voltaire and Hall Point in the Kimberley region form a group at the top of the plot that is discrete from all of those at the other 5 locations at the bottom. However, unlike the situation at Cape Voltaire, the samples from Hall Point are separated more on the basis of depth than season, which accounts, in part, for the interaction between location, season and depth. In the 5 most southern locations, the samples from the dry season lie to the left and/or below all but one of those from the wet season. The samples from the dry and wet seasons in deep water at

that for depth, removing the combined effects of location and season, was 0.68 (all at $p<0.001$ ). However, these tests of strong averaged effects did contain some significant interactions (see above).

Two-way ANOSIM comparisons between the ichthyofaunal compositions at pairs of locations (again removing depth and season effects) showed that the species composition at each location differed significantly from that at each other location $(p=0.1$ to
Emeriau Point are closely apposed and relatively discrete from those in shallow water at this location, which are more widely dispersed, and thus together contribute to the interaction between season and depth.

RELATE analysis demonstrated that the similarity matrix used to produce the ordination plot in Fig. 4 was correlated with the distance matrices constructed at higher taxonomic levels, i.e. genus $(\rho=$ 
Table 4. Mean squares (MS), pseudo F-ratios, significance level (p) and components of variation (COV) for location $\times$ season $x$ depth PERMANOVA for the Bray-Curtis matrix derived from density data for various fish species collected over soft substrata by trawling at 7 locations along the tropical north-western Australian coast in deep and shallow waters during the dry (2001) and wet (2002) season

\begin{tabular}{|lccccr|}
\hline Source & df & MS & Pseudo F & p (perm) & COV \\
\hline Location (L) & 6 & 23237 & 19.6 & $<0.001$ & 1407.5 \\
Season (S) & 1 & 12999 & 10.9 & $<0.001$ & 215.9 \\
Depth (D) & 1 & 9585 & 8.1 & $<0.001$ & 153.5 \\
L x S & 6 & 4839 & 4.1 & $<0.001$ & 466.4 \\
L x D & 6 & 7944 & 6.7 & $<0.001$ & 862.8 \\
D x S & 1 & 1487 & 1.2 & 0.2 & 11.1 \\
L x S D & 6 & 2606 & 2.2 & $<0.001$ & 362.6 \\
Residuals & 82 & 1186 & & & 1186.1 \\
Total & 109 & & & & \\
\hline
\end{tabular}

0.96), family (0.93), sub-order (0.85) and order (0.60). Thus, the pattern of distribution of points shown in the nMDS ordination derived using species data (Fig. 4) was strongly retained when the multivariate analyses were conducted at higher taxonomic levels and particularly up to suborder.

\section{Relationship between species composition and both season and water depth at each location}

On the ordination plots for the various locations, the samples from deep and shallow waters in the dry season could be rotated to lie entirely or very largely above those from deep and shallow waters in the wet season at all locations except Emeriau Point, where only the samples from shallow waters were separated on the basis of season (Fig. 5A-G). The samples from deep and shallow waters at each location also typically showed limited overlap, with those from shallow water being able to be rotated to lie entirely or very largely to the right of those from deep water at all locations except Cape Voltaire (Fig. 5A).

Species composition differed significantly between both dry and wet seasons and deep and shallow waters at every location except Cape Voltaire, where it differed significantly only between seasons (Table 5). The $\bar{R}$-statistic values emphasised that the magnitude of the differences in ichthyofaunal composition between both seasons and water depths were greatest at

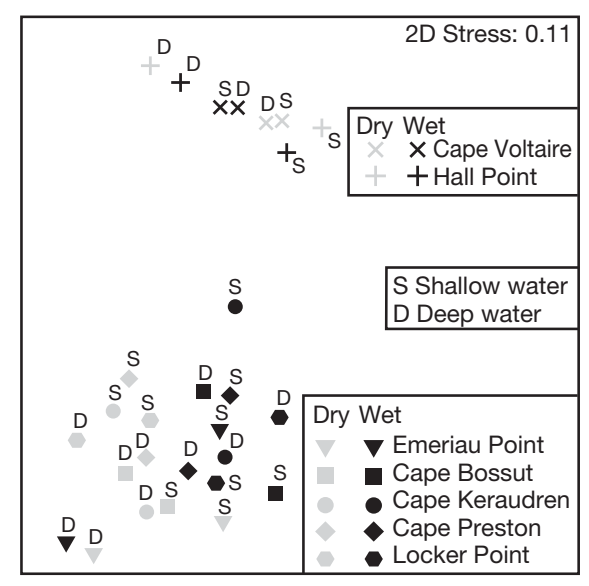

Fig. 4. Non-metric multidimensional scaling (nMDS) ordination derived from matrix constructed from densities of each fish species over soft substrata in deep and shallow waters at 7 locations in north-western Australia during the dry (2001) and wet (2002) seasons
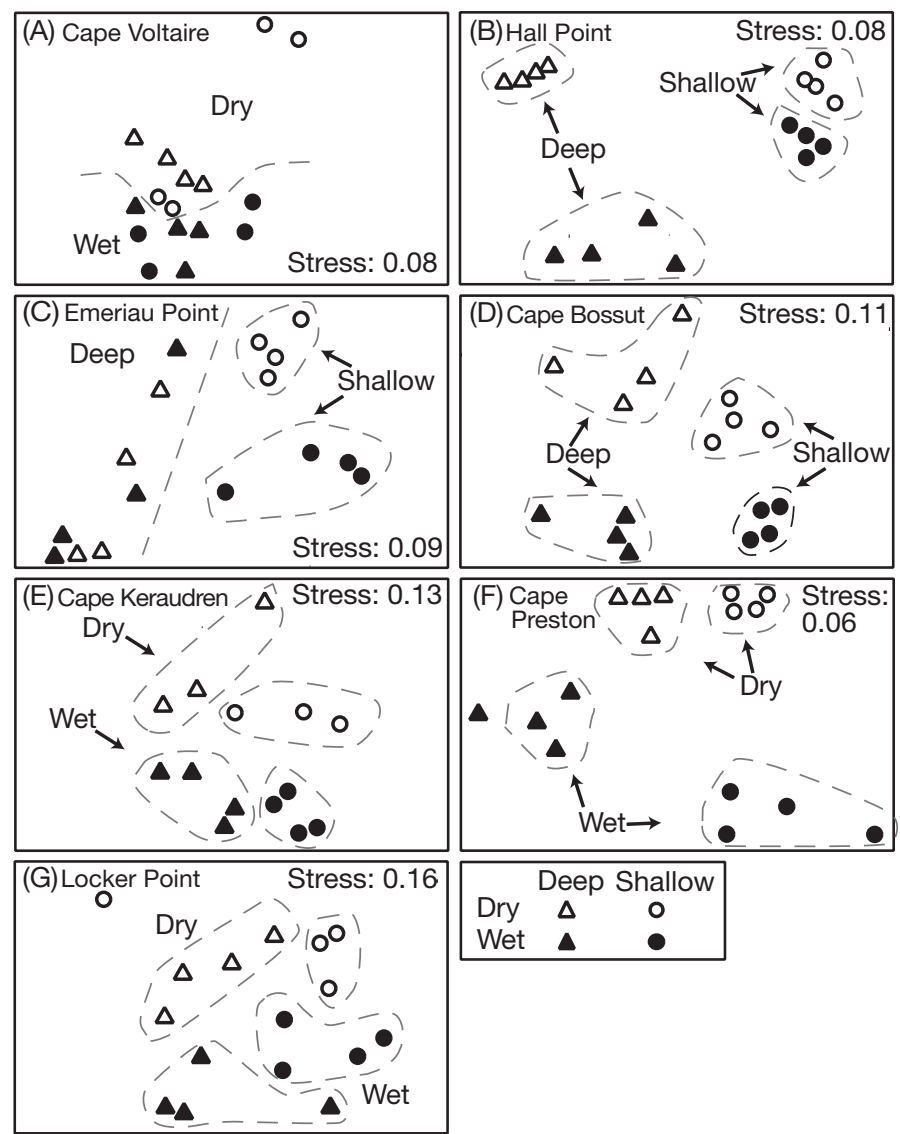

Fig. 5. Non-metric multidimensional scaling (nMDS) ordinations of densities of various fish species caught by trawling over soft substrata in deep and shallow waters at (A) Cape Voltaire, (B) Hall Point, (C) Emeriau Point, (D) Cape Bossut, (E) Cape Keraudren, (F) Cape Preston and (G) Locker Point in the dry (2001) and wet (2002) seasons 
Table 5. Global $R$-statistic values and significance levels for season $\times$ depth 2 -way crossed ANOSIM tests, carried out separately for each location, using data for samples collected over soft substrata in dry and wet seasons. ${ }^{*} \mathrm{p}<0.05$; ${ }^{* *} \mathrm{p}<0.01 ;{ }^{* * *} \mathrm{p}<0.001$

\begin{tabular}{|lll|}
\hline Location & Season & Depth \\
\hline Cape Voltaire & $0.69^{* *}$ & 0.14 \\
Hall Point & $0.90^{* * *}$ & $1.00^{* * *}$ \\
Emeriau Point & $0.38^{*}$ & $0.76^{* *}$ \\
Cape Bossut & $0.83^{* *}$ & $0.70^{* *}$ \\
Cape Keraudren & $0.78^{* *}$ & $0.64^{* *}$ \\
Cape Preston & $0.97^{* * *}$ & $0.98^{* *}$ \\
Locker Point & $0.48^{* *}$ & $0.59^{* * *}$ \\
\hline
\end{tabular}

Hall Point and Cape Preston and least at Cape Voltaire and Locker Point. Two-way crossed SIMPER emphasised that, at Cape Voltaire and Hall Point, the mullid Upeneus sulphureus was present in such far greater densities in the wet than dry seasons (Table 1) that it was the most important species for distinguishing between the faunas in those 2 seasons (Table 6). There was also a strong tendency for the densities of leiognathid species and the carangid Carangoides malabaricus to be consistently greater at those 2 northern locations. Far greater densities of the carangid Selaroides leptolepis and far lower densities of the flounder Engyprosopon grandisquama distinguished the ichthyofaunal composition in the wet from dry seasons at the southernmost locations. At Cape Bossut, Cape Preston and Locker Point, the ichthyofaunas in deep waters were distinguished from those in shallow waters by relatively greater densities of Pseudorhombus argus (Table 7). Greater densities of the mullid $U$. assymetricus and the siganid Siganus fuscescens distinguished the faunas of shallow from deep waters at 3 and 2 of the most southern locations, respectively.

\section{Relationship between fish assemblages and environmental variables}

The linkage tree in Fig. 6 represents the separation of the 28 combinations of location, depth and season into groups identified by a divisive cluster analysis of the species composition of the fish faunas, together with 'explanations' of those bifurcations in terms of thresholds on individual environmental variables. The separations of the faunas at the 2 locations in the Kimberley from those in the 5 locations in the Canning and Pilbara further south were explainable by a combination of greater tidal ranges and lower water
Table 6. Species detected by SIMPER as distinguishing the fish assemblage in the dry (2001) from that in the wet (2002) season at each of 7 locations in north-western Australia, listed in decreasing order of their contribution to the average dissimilarity between the 2 seasons. Any particularly high (>1.5) ratios of dissimilarity (Diss) to SD are in bold for relevant species, i.e. indicating consistent discriminators. ${ }^{*}$ Species favouring dry over wet season

\begin{tabular}{|c|c|c|c|}
\hline \multirow{2}{*}{$\begin{array}{l}\text { Distinguishing } \\
\text { species }\end{array}$} & \multicolumn{3}{|c|}{ Mean density Diss:SD } \\
\hline & Dry & Wet & \\
\hline \multicolumn{4}{|l|}{ Cape Voltaire } \\
\hline Upeneus sulphureus & 11.2 & 223.8 & 2.1 \\
\hline Leiognathus splendens & 185.1 & 1401.1 & 1.2 \\
\hline Secutor insidiator & 0.2 & 741.8 & 1.3 \\
\hline Leiognathus bindus & 0.1 & 31.7 & 2.0 \\
\hline Terapon theraps & 95.0 & 280.5 & 1.3 \\
\hline Leiognathus equulus* & 54.2 & 9.3 & 1.9 \\
\hline Carangoides malabaricus & 59.1 & 191.4 & 1.7 \\
\hline \multicolumn{4}{|l|}{ Hall Point } \\
\hline Upeneus sulphureus & 0.2 & 210.4 & 2.5 \\
\hline Leiognathus leuciscus & 12.8 & 235.6 & 2.2 \\
\hline Terapon theraps & 62.2 & 462.1 & 2.0 \\
\hline Carangoides malabaricus & 1.1 & 27.8 & 1.6 \\
\hline Caranx bucculentus & 52.8 & 142.1 & 1.4 \\
\hline Pseudorhombus arsius & 6.5 & 10.9 & 2.0 \\
\hline Leiognathus moretoniensis & 2.7 & 13.8 & 2.1 \\
\hline \multicolumn{4}{|l|}{ Emeriau Point } \\
\hline Paramonacanthus choirocephalus & 0.5 & 60.0 & 1.1 \\
\hline Selaroides leptolepis & 0.4 & 11.9 & 1.3 \\
\hline Pentapodus porosus & 2.7 & 8.3 & 1.4 \\
\hline Tragulichthys jaculiferus* & 1.3 & 0.3 & 1.2 \\
\hline Synodus sageneus* & 2.8 & 1.5 & 1.2 \\
\hline \multicolumn{4}{|l|}{ Cape Bossut } \\
\hline Selaroides leptolepis & $<0.1$ & 45.1 & 0.9 \\
\hline Torquigener pallimaculatus & 1.7 & 12.3 & 1.8 \\
\hline Engyprosopon grandisquama* & 5.2 & 0.1 & 1.5 \\
\hline Choerodon cephalotes* & 6.3 & 0.2 & 1.3 \\
\hline Synodus dermatogenys* & 2.9 & $<0.1$ & 2.0 \\
\hline Pseudorhombus spinosus* & 2.3 & $<0.1$ & 1.5 \\
\hline \multicolumn{4}{|l|}{ Cape Keraudren } \\
\hline Selaroides leptolepis & $<0.1$ & 345.3 & 2.4 \\
\hline Paramonacanthus choirocephalus & 21.1 & 29.4 & 1.5 \\
\hline Lagocephalus scleratus & 0.7 & 16.7 & 1.5 \\
\hline Chaetodontoplus duboulayi* & 8.4 & 3.3 & 1.4 \\
\hline Engyprosopon grandisquama* & 9.0 & 0.2 & 1.3 \\
\hline Pentapodus vitta & 1.6 & 9.9 & 1.8 \\
\hline \multicolumn{4}{|l|}{ Cape Preston } \\
\hline Paramonacanthus choirocephalus* & 149.3 & 1.8 & 3.5 \\
\hline Engyprosopon grandisquama* & 27.6 & 0.3 & 3.3 \\
\hline Siganus fuscescens* & 21.7 & 7.9 & 1.8 \\
\hline Trachinocephalus myops* & 6.8 & 0.7 & 2.8 \\
\hline Saurida spp. & 32.5 & 78.0 & 1.6 \\
\hline Selaroides leptolepis & $<0.1$ & 18.0 & 1.0 \\
\hline \multicolumn{4}{|l|}{ Locker Point } \\
\hline Paramonacanthus choirocephalus* & * 24.0 & 1.7 & 1.2 \\
\hline Torquigener pallimaculatus* & 13.0 & 0.9 & 1.5 \\
\hline Trachinocephalus myops* & 8.8 & 0.2 & 1.3 \\
\hline Engyprosopon grandisquama* & 17.4 & 0.3 & 1.3 \\
\hline Selaroides leptolepis & $<0.1$ & 35.1 & 1.0 \\
\hline Nemipterus furcosus & 1.8 & 19.2 & 1.0 \\
\hline
\end{tabular}


Table 7. Species detected by SIMPER as distinguishing the fish assemblage in deep water from that in shallower water at each of 6 locations in north-western Australia, listed in decreasing order of their contributions. Any particularly high (>1.5) ratios of dissimilarity (Diss) to SD are in bold, indicating especially consistent discriminators. ${ }^{*}$ Species favouring deep over shallow waters

\begin{tabular}{|c|c|c|c|}
\hline $\begin{array}{l}\text { Distinguishing } \\
\text { species }\end{array}$ & \multicolumn{3}{|c|}{$\begin{array}{l}\text { Mean density Diss:SD } \\
\text { Deep Shallow }\end{array}$} \\
\hline Cape Voltaire & \multicolumn{3}{|c|}{ Not significant } \\
\hline Hall Point & & & \\
\hline Selaroides leptolepis & - & 22.7 & 2.6 \\
\hline Caranx bucculentus & 16.6 & 72.2 & 1.3 \\
\hline Leiognathus splendens* & 43.3 & 16.2 & 2.3 \\
\hline Carangoides humerosus & $<0.1$ & 15.4 & 1.9 \\
\hline Johnius borneensis ${ }^{*}$ & 25.4 & - & 1.5 \\
\hline Ulua aurochs & - & 15.2 & 2.9 \\
\hline Thryssa setirostris* & 9.2 & - & 2.2 \\
\hline Leiognathus leuciscus & 6.7 & 44.2 & 1.6 \\
\hline \multicolumn{4}{|l|}{ Emeriau Point } \\
\hline Saurida spp. & 0.6 & 33.9 & 2.8 \\
\hline Chaetodontoplus duboulayi* & 13.0 & 0.2 & 2.2 \\
\hline Paramonacanthus choirocephalus & S 0.7 & 59.8 & 1.1 \\
\hline Choerodon vitta* & 14.3 & 1.0 & 1.7 \\
\hline Choerodon cephalotes* & 10.1 & 0.8 & 2.4 \\
\hline Coradion chrysozonus* & 5.3 & 0.2 & 1.4 \\
\hline \multicolumn{4}{|l|}{ Cape Bossut } \\
\hline Pristotis obtusirostris & 6.2 & 65.3 & 1.6 \\
\hline Pentapodus porosus* & 7.8 & 1.2 & 1.7 \\
\hline Saurida spp.* & 30.8 & 7.9 & 1.6 \\
\hline Paramonacanthus choirocephalus* & * 4.2 & 1.0 & 1.9 \\
\hline Parapercis nebulosa* & 3.4 & 1.4 & 1.5 \\
\hline Pseudorhombus argus* & 2.6 & 0.8 & 1.8 \\
\hline \multicolumn{4}{|l|}{ Cape Keraudren } \\
\hline Pristotis obtusirostris* & 171.6 & 0.6 & 2.1 \\
\hline Leiognathus leuciscus & - & 37.3 & 1.4 \\
\hline Torquigener pallimaculatus* & 35.2 & 7.5 & 2.2 \\
\hline Pentapodus porosus* & 9.5 & 1.9 & 1.8 \\
\hline Paramonacanthus choirocephalus & S 11.4 & 39.1 & 1.3 \\
\hline Upeneus asymmetricus & 10.7 & 33.6 & 1.4 \\
\hline Nemipterus furcosus* & 9.9 & 0.8 & 1.3 \\
\hline Chaetodontoplus duboulayi* & 6.1 & 4.9 & 1.5 \\
\hline Pseudorhombus arsius & 0.3 & 3.1 & 1.6 \\
\hline \multicolumn{4}{|l|}{ Cape Preston } \\
\hline Upeneus asymmetricus & 0.4 & 17.6 & 1.3 \\
\hline Siganus fuscescens & 2.4 & 27.1 & 1.3 \\
\hline Priacanthus tayenus & 0.1 & 13.6 & 1.4 \\
\hline Pseudorhombus arsius & 0.2 & 4.7 & 2.3 \\
\hline Crossorhombus azureus* & 4.6 & 0.1 & 2.1 \\
\hline Pseudorhombus argus* & 3.2 & 0.2 & 1.4 \\
\hline Paramonacanthus choirocephalus & S 24.4 & 126.7 & 1.7 \\
\hline \multicolumn{4}{|c|}{ Locker Point } \\
\hline Lethrinus genivittatus & 12.7 & 157.0 & 1.0 \\
\hline Pristotis obtusirostris & 12.0 & 49.3 & 1.2 \\
\hline Nemipterus furcosus* & 20.6 & 0.3 & 1.1 \\
\hline Engyprosopon maldiviensis* & 53.7 & - & 1.1 \\
\hline Siganus fuscescens & 1.0 & 14.3 & 1.1 \\
\hline Choerodon cephalotes & 2.5 & 7.9 & 2.0 \\
\hline Saurida spp..$^{*}$ & 36.9 & 19.2 & 1.3 \\
\hline Upeneus asymmetricus & 9.1 & 11.5 & 1.3 \\
\hline Pseudorhombus argus* & 3.6 & 0.2 & 1.3 \\
\hline Paramonacanthus choirocephalus & s 3.6 & 22.1 & 1.3 \\
\hline
\end{tabular}

clarity. Greater chl a concentrations, i.e. greater primary productivity, water temperatures and rainfall were important in explaining the difference between the faunas in the wet and dry seasons in the Kimberley, and higher water temperatures were also important for explaining the differences between the faunas in the wet and dry seasons in both the Canning and Pilbara (Fig. 6). The distinction between the faunas in the Canning and Pilbara during the dry season was related to a greater tidal range and lower productivity in the former bioregion. The split between the samples from the deeper water in both dry and wet seasons at Emeriau Point from those of all other samples from the Canning and Pilbara were associated with the unique substratum type (hard sand with sponge and gorgonian corals) in the deep waters at that Canning location.

\section{DISCUSSION}

\section{Species richness and density of fishes}

This study demonstrated that, in the dry season in NWA, the species richness and density of fishes over soft substrata in deep water both underwent the same remarkably consistent 'concave' pattern of change in a southwards direction along this extensive tropical coast, and that this trend was largely followed also by density in shallow waters. Thus, both of these variables declined progressively with latitude from high levels in the Kimberley to their lowest levels in the Canning and then rose in the Pilbara. Furthermore, species richness in shallow water in the dry season was also least in the first 2 of the Canning locations, i.e. Emeriau Point and Cape Bossut. The above trends imply that, in the dry season, the Kimberley and Pilbara regions provide an environment, which, in terms of productivity and other factors, is more beneficial for a wide range of demersal fish species than the intervening Canning region. It is thus relevant that chl a concentrations, and thus primary productivity, in the dry season are greater in the Kimberley and Pilbara regions than in the Canning region (Condie \& Dunn 2006). Furthermore, very extensive mangrove forests are present in nearshore waters along the coast and in the mouths of creeks and rivers of the Kimberley region and, to a lesser extent, in certain parts of the Pilbara, whereas such substantial forests are not found in the Canning region. Mangrove forests are typically very productive ecosystems, supporting the abundant suite of benthic invertebrates that constitute the prey of many bottom-dwelling fish 


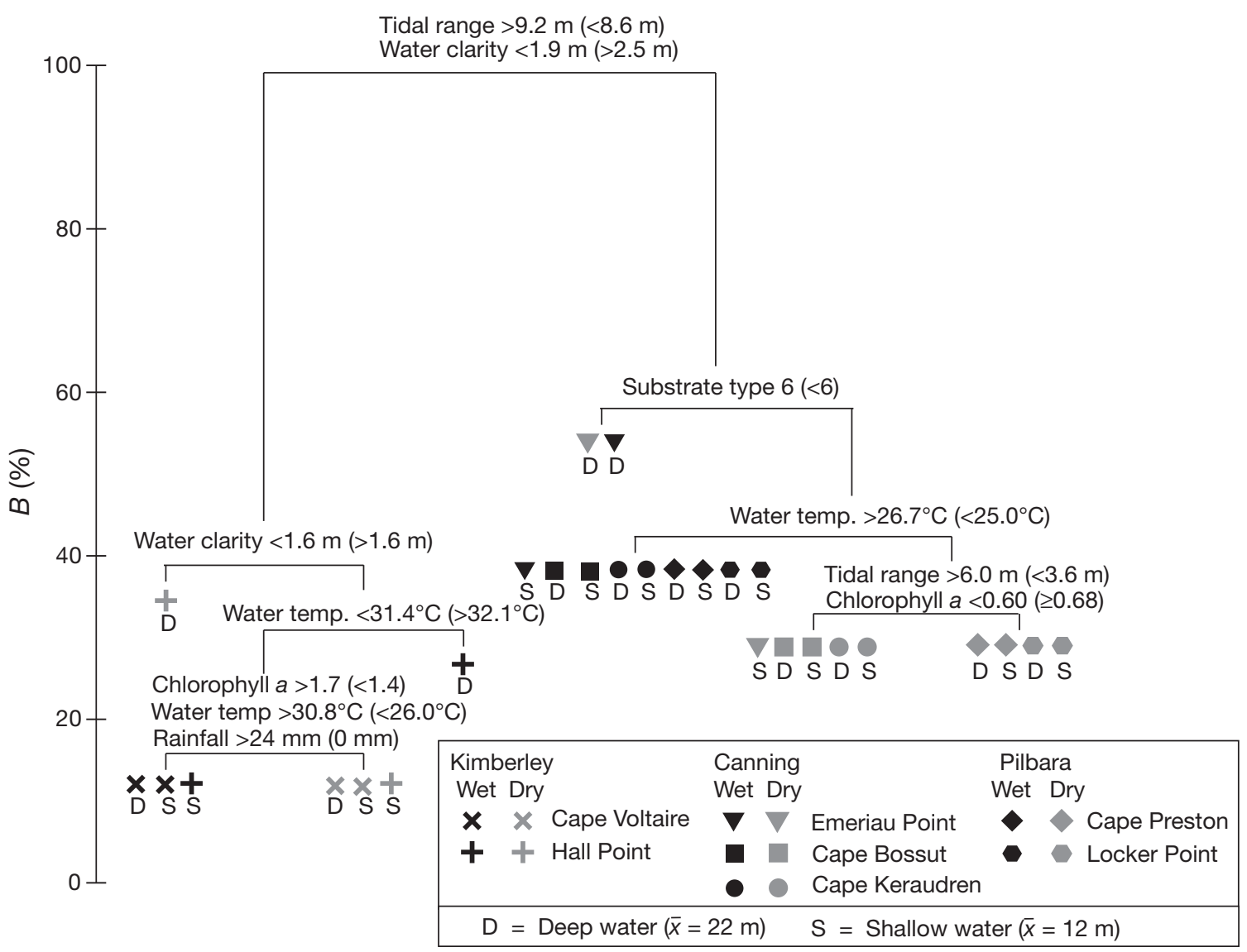

Fig. 6. Linkage tree and associated physical and environmental variable thresholds that relate to the separation of the soft substratum fish communities of inshore waters in north-western Australia. Unbracketed and bracketed thresholds at each branching node indicate that a left and right path, respectively, should be followed through the tree. Chl $\mathrm{a}$ in $\mathrm{mg} \mathrm{m}^{-3}$

species and providing protection from predation for the juveniles of fish species that move further from the shore as they increase in size and/or become mature (Robertson \& Duke 1987, Robertson \& Blaber 1992, Blaber et al. 1995, Alongi 1998, Manson et al. 2005a). Indeed, teleosts such as Siganus fuscescens and Saurida spp., which are abundant as juveniles in mangroves along the Pilbara coast (Blaber et al. 1985), were numerous as adults at Cape Preston and Locker Point in the Pilbara (Table 1).

As the species richness and density of fishes in deep and shallow waters in the wet season followed the same overall sequential downward trend with latitude between Cape Voltaire in the north and Cape Bossut in the middle of the Canning as occurred in the dry season, the greater productivity in the Kimberley than the Canning, and the benefits derived from the mangrove forests found in that region, presumably likewise played a major role in driving that trend. The species richness and density in both deep and shallow waters at the 2 Kimberley locations were far greater, however, during the wet than dry seasons. It is thus relevant that the amount of nutrients discharged by rivers and creeks into the inshore waters in the Kimberley increases markedly during the wet and warmer season (Condie \& Dunn 2006), leading to a rise in primary productivity and consequently sequential increases in abundance upwards through the trophic levels within the food chain. Furthermore, turbidity was far greater in the 2 Kimberley locations than at all other locations, particularly during the wet season, and thus, as elsewhere, would have reduced the likelihood of predation (Blaber \& Blaber 1980, Cyrus \& Blaber 1987).

As species richness in the shallow and particularly the deeper waters at Locker Point, and density in deeper waters, were greater in the dry than wet seasons, it is noteworthy that this location was atypical in that productivity peaked during the dry rather than wet season (Acker \& Leptoukh 2007). Density in shallow water was slightly greater, however, in the wet than dry season. 
Species richness in shallow water during the dry season declined between Cape Keraudren and Locker Point, whereas the converse trend was exhibited by those 2 biotic variables in deep water and by density between Cape Preston and Locker Point. This suggests that, during this season, some species tend to move from shallow to deep water at the more southern locations. It thus appears relevant that water temperature at the most southern locations was greater in the deeper than shallow waters in the dry season, whereas the reverse applied in the wet season. As species richness and density in both depths in the wet season at Cape Keraudren were far greater than those at each of the neighbouring locations, it appears pertinent that the major cyclone, which crossed the coast at Cape Keraudren 3 wk prior to sampling in the wet season, would have led to local mixing of shelf sediments and increases in chl a (McKinnon et al. 2003, Condie et al. 2009) and thus to the provision of a rich source of food for fish species. The pronounced peaks in species richness and abundance of fishes at Cape Keraudren during the wet season could thus reflect an immigration of fishes into that productive location from waters to the north and south.

\section{Relationships between species composition and bioregion}

Our analyses, using LINKTREE, emphasise that, irrespective of season and water depth, there is a trenchant separation between the compositions of the ichthyofaunas of the Kimberley bioregion and those of the Canning and Pilbara bioregions. This new technique showed that these pronounced interregional differences, which reflect, in particular, far higher densities of 2 species of both leiognathids and carangids and 1 species of terapontid and mullid at the northern locations, could be explained by the effects of the greater turbidity and tidal ranges of the coastal waters of the Kimberley bioregion. Leiognathids possess adaptations, such as a bioluminescent system, that would be particularly advantageous for life in these turbid waters (Woodland et al. 2002, Sparks et al. 2005, Borsa et al. 2007). Furthermore, leiognathids and the other above species use mangroves as nursery areas (Robertson \& Duke 1987, Blaber \& Milton 1990, Kimani et al. 1996, Ikejima et al. 2003), which are particularly abundant in the Kimberley region. The above species are also abundant over soft substrata in turbid inshore waters of northern Australia (Ramm et al. 1990, Blaber et al. 1994a, 1995), Indonesia, Malaysia and Thailand
(Pauly \& Matosbroto 1996, Nurhakim 2003), and thus form part of the rich shallow turbid-water fish fauna that extends northwards and eastwards from NWA.

\section{Relationships between species composition and season}

Our analyses also emphasised that, overall, the ichthyofaunal composition along the extensive NWA coast is influenced markedly by season (wet versus dry) and water depth (Figs. 4 \& 5). Indeed, ichthyofaunal composition differed significantly between seasons at all 7 locations and between water depths at all of those locations except Cape Voltaire. The extent of these differences are emphasised by the $\bar{R}$ statistic for both season and depth in 2-way crossed ANOSIM tests always exceeding $\sim 0.5$ at all locations, except with depth at Cape Voltaire and season at Emeriau Point, and being as high as 0.9 to 1.0 for both factors at Hall Point and Cape Preston. The substantial differences between the compositions in each season and in both water depths at all locations except Cape Voltaire and Emeriau Point are also emphasised by the discreteness of the samples for those 4 groups on the ordination plots for all but the last 2 locations (Fig. 5B,D-G). The samples for the dry and wet seasons at Cape Voltaire and for shallow water in the dry and wet seasons at Emeriau Point, however, also formed distinct groups.

The use of LINKTREE emphasised that greater concentrations of chl a (i.e. increased productivity) and higher rainfall (i.e. increased freshwater discharge) and water temperatures were important environmental variables for explaining the separation of the ichthyofaunal compositions in the wet and dry seasons in the Kimberley bioregion and particularly at Cape Voltaire. This is presumably related to differences in the extents of the effects on the reproduction and recruitment of the various fish species in the wet and dry seasons in the Kimberley that would be brought about by the very different levels of productivity and temperature. The rise in productivity and temperature in the wet season would enhance the reproduction and growth of many fish species and the invertebrates that constitute their prey.

The leiognathids, whose far greater densities in the wet than dry season were important for distinguishing between the faunas in those seasons at locations within the Kimberley, included Leiognathus splendens, L. bindus, L. leuciscus, L. moretoniensis and Secutor insidiator (Table 5). As these schooling planktivores are recruited into waters along the 
NWA coast during the wet season (Staunton-Smith et al. 1999) and feed on copepods and ostracods early in their life cycle (Woodland et al. 2001), their juveniles would be able to capitalise on the abundant source of planktivorous food that becomes available during that productive season (Blaber \& Blaber 1980, Blaber et al. 1990, Thorrold \& McKinnon 1995, McKinnon et al. 2003). The large numbers of these small teleosts provide, in turn, a rich source of food for fish species such as Carangoides malabaricus, Terapon theraps, Caranx bucculentus, Pomadasys maculatus and Pseudorhombus arsius, and would thus account for the marked rise in the densities of those piscivorous species in the wet season (Blaber et al. 1989; Table 5). Furthermore, as the mullid Upeneus sulphureus and the adults of leiognathid species feed on benthic macroinvertebrates (Platell et al. 1998, Lukoschek \& McCormick 2001, Hajisamae 2009), the pronounced increases in their densities during the wet season presumably reflect the increases that have been shown to occur in those types of prey during that season (Ward \& Rainer 1988).

The results of LINKTREE emphasise that, with the exception of the deep waters at Emeriau Point, higher water temperatures were important in explaining the marked distinction between the compositions in the Canning and Pilbara regions during the wet season from those in these regions during the dry season. Thus the marked differences in temperature of up to $10^{\circ} \mathrm{C}$ between those seasons at these regions apparently led to the immigration of some fish species and/or to the emigration of others. The only species that consistently played a role in distinguishing between the ichthyofaunas in the wet and dry seasons in the Canning and Pilbara regions was Selaroides leptolepis, which is a schooling planktivore that is recruited into inshore waters during the wet season through the action of wind-driven easterly movements of water (Shuntov 1971).

LINKTREE also demonstrated that a lower tidal range and greater productivity best explained the differences between the compositions of the Pilbara and Canning regions during the dry season. This again suggests that, particularly during the dry season, the Pilbara region provides an environment, which, in terms of productivity and other factors, is more beneficial for a range of demersal fish species than the Canning region immediately to its north. It is thus relevant that nitrates are transported from offshore deeper waters towards the Pilbara coast in the early part of the dry season as a result of a weakening in the poleward flow of the Leeuwin Current (Holloway et al. 1985, Furnas 2007, Thompson et al. 2011).

\section{Relationships between species composition and depth}

Our results demonstrate that, at all locations except Cape Voltaire, the compositions of the fish faunas in the deep and shallow water sites were conspicuously different, even though the mean depths differed by only 10 to $14 \mathrm{~m}$. This parallels the situation recorded over soft substrata in the Gulf of Carpentaria in tropical northern Australia, where the compositions of the fish faunas changed progressively in successive water depths of 2.9 to $4.2,5.0$ to 10.6 and 15.6 to 21.9 m (Rainer \& Munro 1982, Rainer 1984). Relatively small differences in water depth have also been shown to be accompanied by changes in ichthyofaunal composition in temperate waters on the south-east and south-west coasts of Australia (Connell \& Lincoln-Smith 1999, Hyndes et al. 1999). Although ichthyofaunal composition did not tend to be related more to water depth than season or vice versa across the locations sampled in our study, it was shown to be consistently related more to water depth than to season over soft substrata along the coasts of Angola (Bianchi 1992) and west coast of Australia (Williams et al. 2001). The differences between the mean depths in our deep and shallow water sites were far less, however, than the 24 to 460 and 200 to $1500 \mathrm{~m}$ differences in the latter 2 studies. The lack of a significant difference between the species composition in deep and shallow waters at Cape Voltaire is almost certainly related to the fact that the numerous islands present at this location have a disruptive effect on the relationships between ichthyofaunal compositions in different water depths (Fig. 1).

The results of SIMPER demonstrated that no species was consistently important in distinguishing between the fish faunas in deep and shallow water depths at more than 3 locations along the length of the NWA coast. Indeed, the only species that distinguished between the compositions in deep and shallow waters at even 3 locations were the mullid $U p$ eneus assymetricus and the bothid Pseudorhombus argus, with the densities of the former being consistently greater in deeper than shallow waters at Cape Keraudren, Cape Preston and Locker Point, whereas the reverse was true for the latter species at Cape Bossut, Cape Preston and Locker Point. However, unlike $P$. argus, its congener $P$. arsius occurred in greater densities in shallow than deeper waters at Cape Preston. Such 'partitioning' by depth is consistent with the report that the former species lives more offshore and in water depths of 13 to $60 \mathrm{~m}$ and that the latter species is typically found in river mouths and along the coast (Amaoka \& Hensley 2001). 
The presence of far greater densities of Caranx bucculentus in shallow than deeper waters at Hall Point is consistent with the results of other studies, which showed that this small carangid is also abundant in similar turbid shallow waters elsewhere in northern Australia, where it feeds predominantly on small fishes and crustaceans (Rainer \& Munro 1982, Brewer et al. 1989, Ramm et al. 1990, Brewer et al. 1994). LINKTREE identified the broadly classified 'substrate type' as a potential discriminator of the distinctive fish fauna in the deep waters at Emeriau Point (Fig. 6). It thus appears relevant that the benthic habitat in these waters were unique amongst those studied in that they contained substantial amounts of sponges, sea whips and gorgonian corals (authors' unpubl. data). Such a view is consistent with the fact that the pomacanthid Chaetodontoplus duboulayi and chaetodontid Coradion chrysozonus, which are unusual in that they feed extensively on sponges (Allen 1981, Lieske \& Myers 1994), were particularly important in distinguishing the fauna in the deep water habitat at Emeriau Point. The finding from SIMPER that the lethrinid Lethrinus genivittatus and labrid Choerodon cephalotes distinguished the faunas in shallow from deep waters at Locker Point can be explained by the fact that seagrass meadows, which are typically used by the juveniles of these species (Fairclough et al. 2008, Nakamura et al. 2009), are abundant in nearshore waters close to Locker Point (Walker \& Prince 1987).

In contrast to the above species, many others are abundant in both deep and shallow waters, which is hardly surprising in view of the relatively small differences in water depth. These include certain leiognathid species, such as Leiognathus bindus and $L$. equulus, which are known to spawn in both deep and shallow waters (Staunton-Smith et al. 1999).

In summary, this study emphasises that the species richness, density and composition of fishes over soft substrata in inshore waters along a very extensive tropical coastline vary with latitude and particularly among bioregions. These differences are related to a number of factors, including marked variations in productivity and whether substantial mangrove forests are present and thus provide important nursery areas for fish that subsequently move further from shore. A divisive clustering technique demonstrated that the major difference between the ichthyofaunal compositions of the bioregions/locations along this coast is explained by the presence of a greater tidal range and turbidity in the most northern bioregion. Within the confines of our study, differences in ichthyofaunal composition are also associated with factors such as atypical substratum characteristics, e.g. the presence of large amounts of sponges and gorgonian corals. Although species composition was related more to latitude than to either season or water depth, the composition at each sampling location was almost invariably strongly related to both of these factors. Differences in composition between wet and dry seasons in the most northern of the 3 bioregions, i.e. Kimberley, are associated with the higher water temperatures and greater fluvial discharge and productivity that characterise the monsoonal wet season in that region. Greater water temperatures also help explain the differences between the ichthyofaunal compositions in the wet from those in the dry season in the Canning and Pilbara bioregions. The species that typified the ichthyofaunas in different bioregions/locations and distinguished between the ichthyofaunas in wet versus dry seasons and deep versus shallow waters have been identified, and the ways in which such differences may be related to variations in the timing of recruitment and pattern of movements are discussed. Our provision of sound quantitative data on the distributions of fish species and elucidation of the factors that influence ichthyofaunal composition along the NWA coast, which is already experiencing increases in water temperatures (Lough 1998, 2008), provides invaluable baseline information for the processes involved in developing marine protected areas and assessing the impact of climate change and nearshore developments on marine resources along this coast.

Acknowledgements. Our gratitude is expressed to the captains and crew of the RV 'Flinders' and 'Naturaliste' of the Department of Fisheries, Western Australia, and to colleagues, particularly C. Skepper, for their invaluable assistance in the field. We also thank F. Valesini, P. Thompson and D. Holliday for helpful discussion on the manuscript. The helpful comments of the anonymous referees have led to a much improved paper. Funding was provided by the Australian Fisheries Research and Development Corporation, Murdoch University and the Department of Fisheries, Western Australia (FRDC Project No. 2000/132). K.R.C. acknowledges his honorary fellowships of the Plymouth Marine Laboratory and the Marine Biological Association of the UK, and his adjunct professorship at Murdoch University.

\section{LITERATURE CITED}

Acker JG, Leptoukh G (2007) Online analysis enhances use of NASA earth science data. Eos Trans AGU 88:14-17

Allen GA (1981) Butterfly and angelfishes of the world, Vol 2, 2nd edn. Mergus, Melle

Allen GR (1997) Marine fishes of tropical Australia and South-East Asia. 3rd edn. Western Australian Museum, Perth

Alongi DM (1998) Coastal ecosystem processes. CRC Press, New York, NY 
Amaoka K, Hensley DA (2001) Paralichthyidae. In: Carpenter KE, Niem VH (eds) FAO species identification guide for fisheries purposes. The living marine resources of the Western Central Pacific, Vol 6: Bony fishes, Part 4 (Labridae to Latimeriidae), estuarine crocodiles, sea turtles, sea snakes and marine mammals. FAO, Rome, p 3842-3862

Anderson MJ (2001) A new method for non-parametric multivariate analysis of variance. Austral Ecol 26:32-46

Anderson MJ, Gorley RN, Clarke KR (2008) PERMANOVA+ for PRIMER: guide to software and statistical methods. PRIMER-E, Plymouth

Behrenfeld MJ, O'Malley RT, Siegel DA, McClain CR and others (2006) Climate-driven trends in contemporary ocean productivity. Nature 444:752-755

> Bellwood DR, Hughes TP (2001) Regional-scale assembly rules and biodiversity of coral reefs. Science 292: 1532-1535

Bianchi G (1992) Demersal assemblages of the continentalshelf and upper slope of Angola. Mar Ecol Prog Ser 81: 101-120

Blaber SJM, Blaber TG (1980) Factors affecting the distribution of juvenile estuarine and inshore fish. J Fish Biol 17: 143-162

Blaber SJM, Milton DA (1990) Species composition, community structure and zoogeography of fishes of mangrove estuaries in the Solomon Islands. Mar Biol 105:259-267

Blaber SJM, Young JW, Dunning MC (1985) Community structure and zoogeographic affinities of the coastal fishes of the Dampier Region of north-western Australia. Aust J Mar Freshw Res 36:247-266

Blaber SJM, Brewer DT, Salini JP (1989) Species composition and biomasses of fishes in different habitats of a tropical northern Australian estuary: their occurrence in the adjoining sea and estuarine dependence. Estuar Coast Shelf Sci 29:509-531

Blaber SJM, Brewer D, Salini J, Kerr JD (1990) Biomasses catch rates and abundances of demersal fishes particularly predators of prawns in a tropical bay in the Gulf of Carpentaria, Australia. Mar Biol 107:397-408

Blaber SJM, Brewer DT, Harris AN (1994a) Distribution, biomass and community structure of demersal fishes of the Gulf of Carpentaria, Australia. Aust J Mar Freshw Res 45:375-396

Blaber SJM, Brewer DT, Salini JP (1994b) Comparisons of fish communities of tropical estuarine and inshore habitats in the Gulf of Carpentaria, northern Australia. In: Dyer KR, Orth RJ (eds) Changes in fluxes in estuaries. Olsen \& Olsen, Fredensborg, p 363-372

Blaber SJM, Brewer DT, Salini JP (1995) Fish communities and the nursery role of the shallow inshore waters of a tropical bay in the Gulf of Carpentaria, Australia. Estuar Coast Shelf Sci 40:177-193

Borsa P, Lemer S, Aurelle D (2007) Patterns of lineage diversification in rabbitfishes. Mol Phylogenet Evol 44:427-435

> Brewer DT, Blaber SJM, Salini JP (1989) Feeding biology of Caranx bucculentus Alleyne and Macleay (Teleostei, Carangidae) in Albatross Bay, Gulf of Carpentaria, with special reference to predation on penaeid prawns. Aust J Mar Freshw Res 40:657-668

Brewer DT, Blaber SJM, Milton DA, Salini JP (1994) Aspects of the biology of Caranx bucculentus (Teleostei, Carangidae) from the Gulf of Carpentaria, Australia. Aust J Mar Freshw Res 45:413-427

Carpenter KE, Niem VH (1998-2001) Species identification guide for fishery purposes. The living marine resources of the western central Pacific, Vol. 2-6. FAO, Rome

Cheal AJ, Coleman G, Delean S, Miller I, Osborne K, Sweatman H (2002) Responses of coral and fish assemblages to a severe but short-lived tropical cyclone on the Great Barrier Reef, Australia. Coral Reefs 21:131-142

Clarke KR (1993) Non-parametric multivariate analyses of changes in community structure. Aust J Ecol 18:117-143

Clarke KR, Gorley RN (2006) PRIMER v6: user manual tutorial. PRIMER-E, Plymouth

Clarke KR, Warwick RM (2001) Change in marine communities: an approach to statistical analysis and Interpretation, 2nd edn. PRIMER-E, Plymouth Marine Laboratory, Plymouth

> Clarke KR, Somerfield PJ, Gorley RN (2008) Testing of null hypotheses in exploratory community analyses: similarity profiles and biota-environment linkage. J Exp Mar Biol Ecol 366:56-69

Condie SA, Dunn JR (2006) Seasonal characteristics of the surface mixed layer in the Australasian region: implications for primary production regimes and biogeography. Mar Freshw Res 57:569-590

Condie SA, Herzfeld M, Margvelashvili N, Andrewartha JR (2009) Modeling the physical and biogeochemical response of a marine shelf system to a tropical cyclone. Geophys Res Lett 36:L22603

Connell SD, Lincoln-Smith MP (1999) Depth and the structure of assemblages of demersal fish: experimental trawling along a temperate coast. Estuar Coast Shelf Sci 48: 483-495

Connolly SR, Bellwood DR, Hughes TP (2003) Indo-Pacific biodiversity of coral reefs: deviations from a mid-domain model. Ecology 84:2178-2190

- Cyrus DP, Blaber SJM (1987) The influence of turbidity on juvenile marine fishes in estuaries. 2. Laboratory studies, comparisons with field data and conclusions. J Exp Mar Biol Ecol 109:71-91

De'Ath G (2002) Multivariate regression trees: a new technique for modeling species-environment relationships. Ecology 83:1105-1117

Fairclough DV, Clarke KR, Valesini FJ, Potter IC (2008) Habitat partitioning by five congeneric and abundant Choerodon species (Labridae) in a large subtropical marine embayment. Estuar Coast Shelf Sci 77:446-456

Furnas M (2007) Intra-seasonal and inter-annual variations in phytoplankton biomass, primary production and bacterial production at North West Cape, Western Australia: links to the 1997-1998 El Niño event. Cont Shelf Res 27: 958-980

Gaertner JC, Mazouni N, Sabatier R, Millet B (1999) Spatial structure and habitat associations of demersal assemblages in the Gulf of Lions: a multicompartmental approach. Mar Biol 135:199-208

Gaertner JC, Bertrand JA, de Sola LG, Durbec JP, Ferrandis E, Souplet A (2005) Large spatial scale variation of demersal fish assemblage structure on the continental shelf of the NW Mediterranean Sea. Mar Ecol Prog Ser 297: 245-257

Gentilli J (1972) Australian climate patterns. Nelson, Melbourne

Gloerfelt-Tarp T, Kailola PJ (1984) Trawled fishes of southern Indonesia and northwestern Australia. Tien Wah Press, Singapore

> Guidetti P (2000) Differences among fish assemblages associated with nearshore Posidonia oceanica seagrass beds, rocky-algal reefs and unvegetated sand habitats in the 
Adriatic Sea. Estuar Coast Shelf Sci 50:515-529

Hajisamae S (2009) Trophic ecology of bottom fishes assemblage along coastal areas of Thailand. Estuar Coast Shelf Sci 82:503-514

> Harris AN, Poiner IR (1991) Changes in species composition of demersal fish fauna of Southeast Gulf of Carpentaria, Australia, after 20 years of fishing. Mar Biol 111:503-519

> Hawkins BA, Diniz JAF (2004) 'Latitude' and geographic patterns in species richness. Ecography 27:268-272

$>$ Heck KL, Able KW, Fahay MP, Roman CT (1989) Fishes and decapod crustaceans of Cape Cod eelgrass meadows: species composition, seasonal abundance patterns and comparison with unvegetated substrates. Estuaries 12: 59-65

> Holloway PE (1983) Tides on the Australian north-west shelf. Aust J Mar Freshw Res 34:213-230

> Holloway PE, Humphries SE, Atkinson M, Imberger J (1985) Mechanisms for nitrogen supply to the Australian North West Shelf. Aust J Mar Freshw Res 36:753-764

> Hughes TP, Bellwood DR, Connolly SR (2002) Biodiversity hotspots, centres of endemicity, and the conservation of coral reefs. Ecol Lett 5:775-784

Hutchins JB (2001) Biodiversity of shallow reef fish assemblages in Western Australia using a rapid censusing technique. Rec Aust Mus 20:247-270

> Hyndes GA, Platell ME, Potter IC, Lenanton RCJ (1999) Does the composition of the demersal fish assemblages in temperate coastal waters change with depth and undergo consistent seasonal changes? Mar Biol 134:335-352

> Ikejima K, Tongnunui P, Medej T, Taniuchi T (2003) Juvenile and small fishes in a mangrove estuary in Trang province, Thailand: seasonal and habitat differences. Estuar Coast Shelf Sci 56:447-457

> Jones GP, Syms C (1998) Disturbance, habitat structure and the ecology of fishes on coral reefs. Aust J Ecol 23: 287-297

Kimani EN, Mwatha GK, Wakwabi EO, Ntiba JM, Okoth BK (1996) Fishes of a shallow tropical mangrove estuary, Gazi, Kenya. Mar Freshw Res 47:857-868

Koslow JA, Kloser RJ, Williams A (1997) Pelagic biomass and community structure over the mid-continental slope off southeastern Australia based upon acoustic and midwater trawl sampling. Mar Ecol Prog Ser 146:21-35

Kuo SR, Lin HJ, Shao KT (2001) Seasonal changes in abundance and composition of the fish assemblage in Chiku Lagoon, southwestern Taiwan. Bull Mar Sci 68:85-99

Last PR, Stevens JD (1994) Sharks and rays of Australia. CSIRO Publishing, Melbourne

Lieske E, Myers R (1994) Collins pocket guide. Coral reef fishes. Indo-Pacific \& Caribbean including the Red Sea. Harper Collins Publishers, New York, NY

Lough JM (1998) Coastal climate of northwest Australia and comparisons with the Great Barrier Reef: 1960 to 1992. Coral Reefs 17:351-367

> Lough JM (2008) Shifting climate zones for Australia's tropical marine ecosystems. Geophys Res Lett 35:L14708

Lukoschek V, McCormick MI (2001) Ontogeny of diet changes in a tropical benthic carnivorous fish, Parupeneus barberinus (Mullidae): relationship between foraging behaviour, habitat use, jaw size, and prey selection. Mar Biol 138:1099-1113

Mahon R, Brown SK, Zwanenburg KCT, Atkinson DB and others (1998) Assemblages and biogeography of demersal fishes of the east coast of North America. Can J Fish Aquat Sci 55:1704-1738
Manson FJ, Loneragan NR, Harch BD, Skilleter GA, Williams L (2005a) A broad-scale analysis of links between coastal fisheries production and mangrove extent: a case-study for northeastern Australia. Fish Res 74:69-85

Manson FJ, Loneragan NR, Skilleter GA, Phinn SR (2005b) An evaluation of the evidence for linkages between mangroves and fisheries: a synthesis of the literature and identification of research directions. Oceanogr Mar Biol Annu Rev 43:483-513

> McKinnon AD, Meekan MG, Carleton JH, Furnas MJ, Duggan S, Skirving W (2003) Rapid changes in shelf waters and pelagic communities on the southern Northwest Shelf, Australia, following a tropical cyclone. Cont Shelf Res 23:93-111

> Morel A, Berthon JF (1989) Surface pigments, algal biomass profiles, and potential production of the euphotic layer: relationships reinvestigated in view of remote-sensing applications. Limnol Oceanogr 34:1545-1562

> Nakamura Y, Shibuno T, Lecchini D, Kawamura T, Watanabe Y (2009) Spatial variability in habitat associations of pre- and post-settlement stages of coral reef fishes at Ishigaki Island, Japan. Mar Biol 156:2413-2419

Nurhakim S (2003) Analysis of demersal assemblages off the north coast of Central Java, Indonesia. In: Silvestre G, Garces L, Stobutzki I, Ahmed M and others (eds) Assessment, management and future directions for coastal fisheries in Asian countries. WorldFish Center Conference Proceedings 67, p 187-206

Pauly D, Matosbroto P (1996) Baseline studies of biodiversity: the fish resources of Western Indonesia. ICLARM, Manilla

Platell ME, Potter IC, Clarke KR (1998) Do the habitats, mouth morphology and diets of the mullids Upeneichthys stotti and U. lineatus in coastal waters of southwestern Australia differ? J Fish Biol 52:389-418

> Porter-Smith R, Harris PT, Andersen OB, Coleman R, Greenslade D, Jenkins CJ (2004) Classification of the Australian continental shelf based on predicted sediment threshold exceedance from tidal currents and swell waves. Mar Geol 211:1-20

Rainer SF (1984) Temporal changes in a demersal fish and cephalopod community of an unexploited coastal area in northern Australia. Aust J Mar Freshw Res 35:747-768

Rainer SF, Munro ISR (1982) Demersal fish and cephalopod communities of an unexploited coastal environment in northern Australia. Aust J Mar Freshw Res 33:1039-1055

Ramm DC, Pender PJ, Willing RS, Buckworth RC (1990) Large-scale spatial patterns of abundance within the assemblage of fish caught by prawn trawlers in northern Australian waters. Aust J Mar Freshw Res 41:79-95

Robertson AI, Blaber SJM (1992) Plankton, epibenthos and fish communities. In: Robertson AI, Alongi DM (eds) Tropical mangrove ecosystems. American Geophysical Union, Washington, DC, p 173-224

> Robertson AI, Duke NC (1987) Mangroves as nursery sites: comparisons of the abundance and species composition of fish and crustaceans in mangroves and other nearshore habitats in tropical Australia. Mar Biol 96:193-205

Robertson AI, Duke NC (1990) Mangrove fish-communities in tropical Queensland, Australia: spatial and temporal patterns in densities, biomass and community structure. Mar Biol 104:369-379

Sainsbury KJ, Kailola PJ, Leyland GG (1985) Continental shelf fishes of northern and north-western Australia. Clouston and Hall, Canberra 
Semeniuk V (1993) The mangrove systems of Western Australia: 1993 presidential address. J R Soc West Aust 76: 99-122

Shuntov VI (1971) Some data on the biology of fishes of the Arafura Sea and their environmental conditions. J Ichthyol 11:1-8

Somerfield PJ, Clarke KR (1995) Taxonomic levels, in marine community studies, revisited. Mar Ecol Prog Ser 127:113-119

Sparks JS, Dunlap PV, Smith WL (2005) Evolution and diversification of a sexually dimorphic luminescent system in ponyfishes (Teleostei: Leiognathidae), including diagnoses for two new genera. Cladistics 21:305-327

Staunton-Smith J, Blaber SJM, Greenwood JG (1999) Interspecific differences in the distribution of adult and juvenile ponyfish (Leiognathidae) in the Gulf of Carpentaria, Australia. Mar Freshw Res 50:643-653

Thackway R, Cresswell ID (1998) Interim Marine and Coastal Regionalisation for Australia: an ecosystembased classification for marine and coastal environments, version 3.3. Environment Australia, Commonwealth Department of the Environment, Canberra

Thompson PA, Wild-Allen K, Lourey M, Rousseaux C, Waite AM, Feng M, Beckley LE (2011) Nutrients in an oligotrophic boundary current: evidence of a new role for the Leeuwin Current. Prog Oceanogr 91:345-359

Thorrold SR, McKinnon AD (1995) Response of larval fish assemblages to a riverine plume in coastal waters of the central Great Barrier Reef lagoon. Limnol Oceanogr 40: 177-181

Thresher RE, Sainsbury KJ, Gunn JS, Whitelaw AW (1986) Life history strategies and recent changes in population structure in the lizardfish genus, Saurida, on the Aus- tralian northwest shelf. Copeia 1986:876-885

Travers MJ, Potter IC (2002) Factors influencing the characteristics of fish assemblages in a large subtropical marine embayment. J Fish Biol 61:764-784

- Travers MJ, Newman SJ, Potter IC (2006) Influence of latitude, water depth, day v. night and wet v. dry periods on the species composition of reef fish communities in tropical Western Australia. J Fish Biol 69:987-1017

Travers MJ, Potter IC, Clarke KR, Newman SJ, Hutchins JB (2010) The inshore fish faunas over soft substrates and reefs on the tropical west coast of Australia differ and change with latitude and bioregion. J Biogeogr 37: 148-169

Walker DI, Prince RIT (1987) Distribution and biogeography of seagrass species on the northwest coast of Australia. Aquat Bot 29:19-32

$>$ Ward TJ, Rainer SF (1988) Decapod crustaceans of the North West Shelf, a tropical continental shelf of north western Australia. Aust J Mar Freshw Res 39:751-765

> Williams A, Koslow JA, Last PR (2001) Diversity, density and community structure of the demersal fish fauna of the continental slope off western Australia (20 to $35^{\circ} \mathrm{S}$ ). Mar Ecol Prog Ser 212:247-263

Woodland DJ, Premcharoen S, Cabanban AS (2001) Leiognathidae. In: Carpenter KE, Niem VH (eds) FAO species identification guide for fisheries purposes. The living marine resources of the Western Central Pacific, Vol 5: Bony fishes, Part 3 (Menidae to Pomacentridae. FAO, Rome, p 2792-2823

> Woodland DJ, Cabanban AS, Taylor VM, Taylor RJ (2002) A synchronized rhythmic flashing light display by schooling Leiognathus splendens (Leiognathidae: Perciformes). Mar Freshw Res 53:159-162

Appendix 1. Additional data on ranking of important families of fishes by abundance and species identified by SIMPER analysis

Table A1. Ranking by abundance of the 10 most abundant families over soft substrates in (A) deep and shallow waters and (B) dry and wet seasons, and percentage contribution of their individuals (n) to total catch

\begin{tabular}{|c|c|c|c|c|c|c|}
\hline $\begin{array}{l}\text { (A) Water depth } \\
\text { Rank }\end{array}$ & Deep water & $\mathrm{n}$ & $\%$ & Shallow water & $\mathrm{n}$ & $\%$ \\
\hline 1 & Leiognathidae & 9474 & 32.5 & Leiognathidae & 17874 & 41.9 \\
\hline 2 & Carangidae & 4742 & 16.3 & Carangidae & 5004 & 11.7 \\
\hline 3 & Terapontidae & 2786 & 9.6 & Terapontidae & 4432 & 10.4 \\
\hline 4 & Synodontidae & 2018 & 6.9 & Mullidae & 3021 & 7.1 \\
\hline 5 & Pomacentridae & 1602 & 5.5 & Monacanthidae & 2046 & 4.8 \\
\hline 6 & Mullidae & 1533 & 5.3 & Synodontidae & 1798 & 4.2 \\
\hline 7 & Bothidae & 755 & 2.6 & Lethrinidae & 1363 & 3.2 \\
\hline 8 & Apogonidae & 713 & 2.4 & Pomacentridae & 1182 & 2.8 \\
\hline 9 & Nemipteridae & 680 & 2.3 & Haemulidae & 890 & 2.1 \\
\hline \multirow[t]{2}{*}{10} & Tetraodontidae & 673 & 2.3 & Tetraodontidae & 541 & 1.3 \\
\hline & Total & & 85.7 & & & 89.5 \\
\hline \multicolumn{7}{|l|}{ (B) Season } \\
\hline Rank & Dry season & $\mathrm{n}$ & $\%$ & Wet season & $\mathrm{n}$ & $\%$ \\
\hline 1 & Leiognathidae & 3046 & 19.2 & Leiognathidae & 24303 & 43.4 \\
\hline 2 & Monacanthidae & 1588 & 10.0 & Carangidae & 8214 & 14.7 \\
\hline 3 & Carangidae & 1533 & 9.7 & Terapontidae & 5950 & 10.6 \\
\hline 4 & Pomacentridae & 1312 & 8.3 & Mullidae & 4010 & 7.2 \\
\hline 5 & Terapontidae & 1270 & 8.0 & Synodontidae & 2692 & 4.8 \\
\hline 6 & Synodontidae & 1123 & 7.1 & Pomacentridae & 1472 & 2.6 \\
\hline 7 & Bothidae & 1005 & 6.3 & Monacanthidae & 997 & 1.8 \\
\hline 8 & Mullidae & 544 & 3.4 & Lethrinidae & 976 & 1.7 \\
\hline 9 & Lethrinidae & 528 & 3.3 & Tetraodontidae & 877 & 1.6 \\
\hline \multirow[t]{2}{*}{10} & Labridae & 444 & 2.8 & Apogonidae & 871 & 1.6 \\
\hline & Total & & 78.3 & & & 90.0 \\
\hline
\end{tabular}




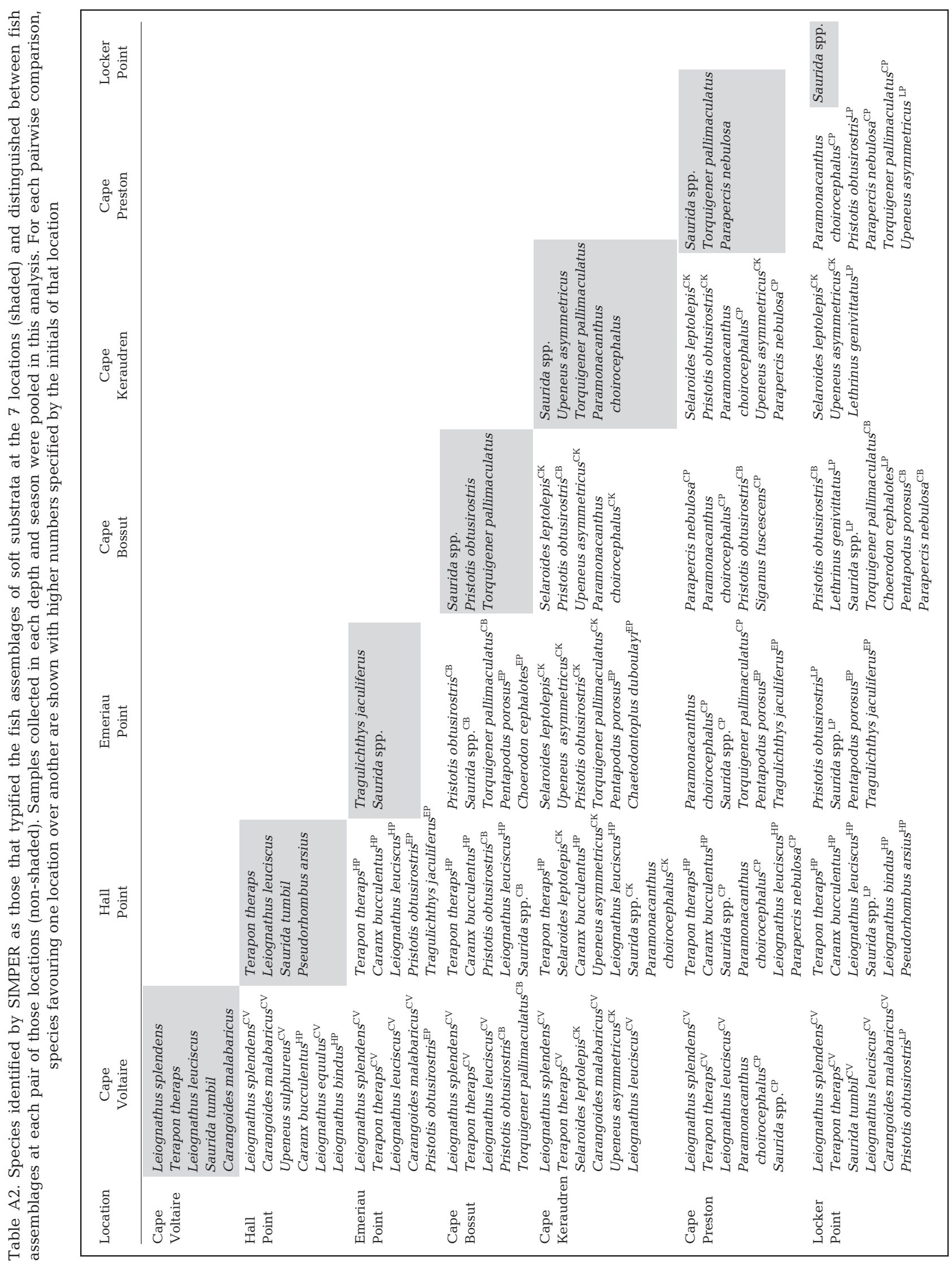

